
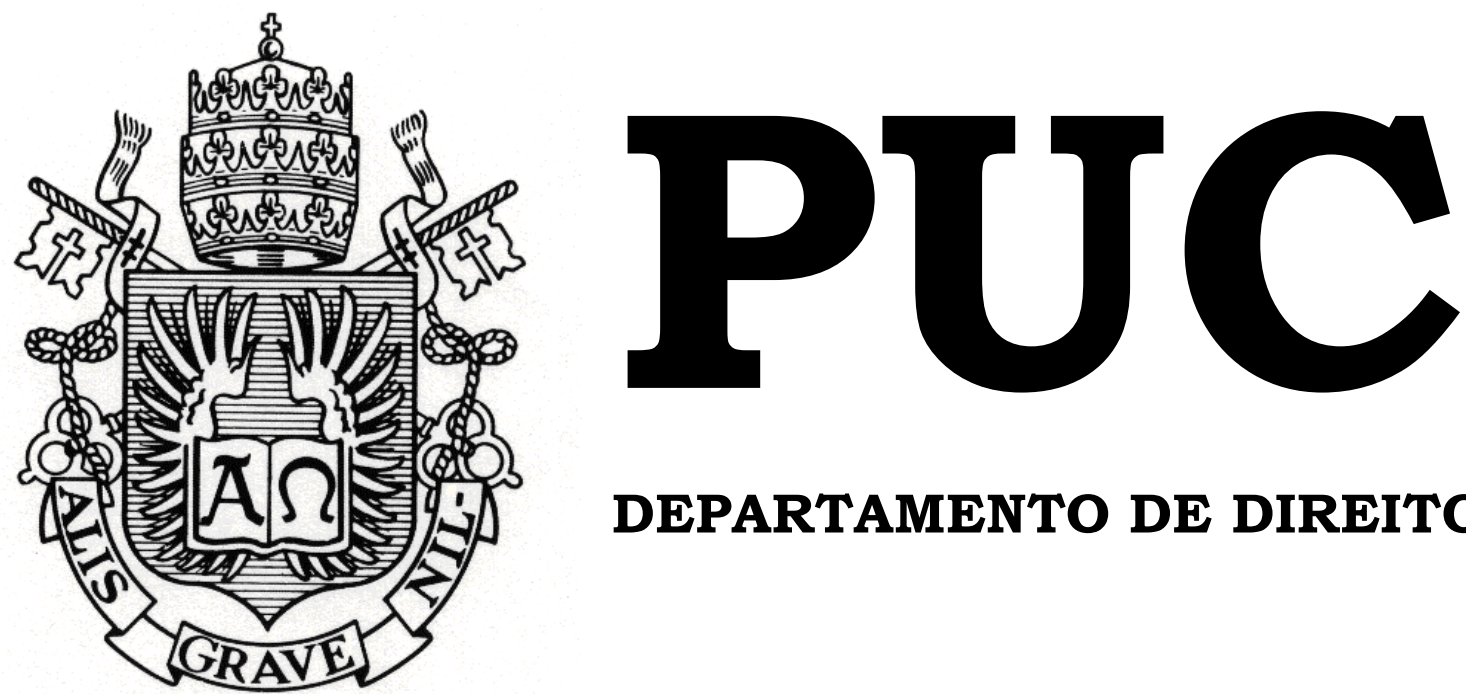

DEPARTAMENTO DE DIREITO

\title{
ASPECTOS POLEMICOS DOS JULGAMENTOS PELO TRIBUNAL DO JÚRI
}

por

MARIANNA ZAMITH GARCIA DE SOUZA

ORIENTADOR: ADOLFO BORGES FILHO

2019.2

PONTIFÍCIA UNIVERSIDADE CATÓLICA DO RIO DE JANEIRO

RUA MARQUÊS DE SÃO VICENTE, 225 - CEP 22453-900

RIO DE JANEIRO - BRASIL 


\section{ASPECTOS POLEMMICOS DOS JULGAMENTOS PELO TRIBUNAL DO JÚRI}

por

MARIANNA ZAMITH GARCIA DE SOUZA

Monografia apresentada ao Departamento de Direito da Pontificia Universidade Católica do Rio de Janeiro (PUCRio) para a obtenção do Título de Bacharel em Direito.

Orientador: Adolfo Borges Filho 
Dedico este trabalho à minha melhor amiga

de todas as horas, o maior presente que Deus me concedeu:

minha amada Mãe. 


\section{AGRADECIMENTOS}

Em primeiro lugar, gratidão ao Senhor e Salvador da minha vida, Jesus Cristo, por permitir que eu seja formada por uma das mais conceituadas faculdades de Direito de todo o país, PUC-Rio. Sou grata por ter me concedido saúde para vencer todos os desafios que foram colocados diante de mim. Foi Ele quem me ensinou o verdadeiro significado da palavra resiliência.

Agradeço à minha amada mãe, Ana Beatriz, pela qualidade inerente à sua pessoa: melhor mãe do mundo. Muito obrigada por vencer, diariamente, as pedras que se acham no meio do caminho, com o objetivo de me proporcionar o melhor deste mundo. Você foi conditio sine qua non para que eu chegasse até aqui. Obrigada por tudo e por tanto. Eu te amo infinitamente.

Ao querido meu avô (in memoriam) João Garcia e à minha querida avó Anna Maria Zamith, por toda educação e carinho. Tenho em vocês meu referencial de amor ao próximo. Gratidão por me ensinarem o valor dos estudos, desde quando eu ainda era uma criança. Devo a vocês minha dedicação aos livros, com muito amor.

Ao meu pai, Sergio Adriano, por ser o meu maior exemplo de perseverança. Pai, sua história é fonte de inspiração para a minha vida. Muito obrigada por desenvolver em mim a paixão pela carreira pública. Admiro muito sua fé em Deus para alcançar suas metas. Te amo.

Ao meu estimado orientador, prof. Adolfo Borges Filho. Por sua cordialidade e paciência em ouvir meus desabafos acadêmicos. Obrigada por ter confiado em meu trabalho. O senhor honra, em todos os aspectos, o ilustre MPRJ. 


\section{RESUMO}

SOUZA, Marianna Zamith Garcia de. Aspectos Polêmicos nos Julgamentos do Tribunal do Júri. Rio de Janeiro, 2019. 65 p. Monografia de final de curso. Departamento de Direito da Pontifícia Universidade Católica do Rio de Janeiro- PUC-Rio.

A presente monografia possui o fito de analisar o instituto do Tribunal do Júri e seus aspectos polêmicos, que podem resultar em anacronias do ponto de vista da ordem constitucional democrática vigente. Além disso, tais aspectos podem ensejar prejuízos à garantia fundamental de julgamento imparcial, bem como ao princípio constitucional implícito relativo à segurança jurídica, no momento de tomada de decisões pelo Conselho de Sentença.

Palavras-Chave: Tribunal do júri; Quórum do Conselho de Sentença; Votações por maioria simples; Incomunicabilidade dos jurados; Interferência midiática; Parcialidade dos jurados; Sistema da íntima convicção; Reflexões acerca da Lei 8.625/93 e Lei Complementar 75/93. 


\section{SUMÁRIO}

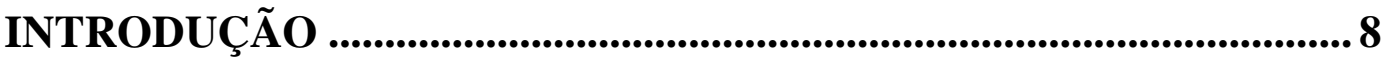

CAPÍTULO I- BREVE HISTÓRICO DO TRIBUNAL DO JÚRI........ 10 CAPÍTULO II- PRINCÍPIOS CONSTITUCIONAIS DO TRIBUNAL

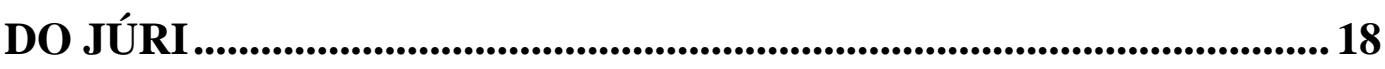

2.1. Considerações preliminares............................................................... 18

2.2. Plenitude de defesa ........................................................................ 19

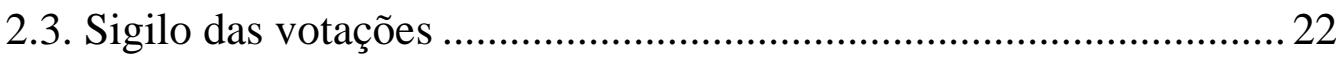

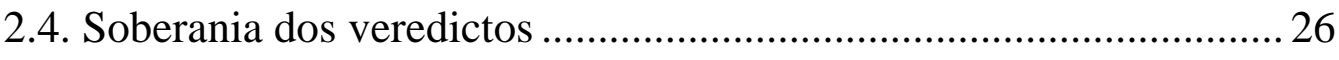

2.5. Da competência para o julgamento dos crimes dolosos contra a vida 28

\section{CAPÍTULO III- ATRIBUTOS DO CONSELHO DE SENTENÇA ....33}

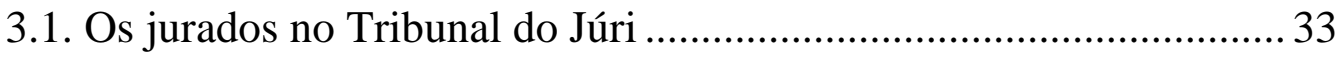

3.2. O quantum de julgadores no Conselho de Sentença ......................... 36

3.3. A incomunicabilidade dos jurados ………………………………..... 40

CAPÍTULO IV- A (IM)PARCIALIDADE NA TOMADA DE

DECISÃO PELOS JURADOS ................................................................45

4.1. A hipótese legal do desaforamento...................................................... 45

4.2. A ausência de motivação na tomada de decisão................................. 48

4.3. O posicionamento simbólico do Ministério Público na sala de

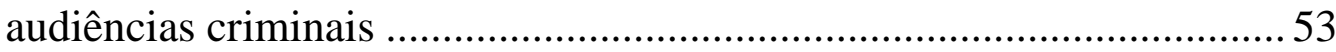

CONCLUSÃO..........................................................................................58

REFERÊNCIAS BIBLIOGRÁFICAS .................................................... 61 


\section{LISTA DE ABREVIAÇÕES}

\&-E

§- Parágrafo

$\%$ - Por cento

ADI- Ação Direta de Inconstitucionalidade

Ago.- Agosto

AgRg- Agravo Regimental

Art.- Artigo

Artss.- Artigos

CE- Ceará

CF- Constituição Federal

CNJ- Conselho Nacional de Justiça

CP- Código Penal

CPP- Código de Processo Penal

D.- Dom

Dez.- Dezembro

DJe- Diário da Justiça Eletrônico

Ed.- Edição

ES- Espírito Santo

Et al.- E outros

HC- Habeas Corpus

J.- Julgado

Jan.- Janeiro

Jun.- Junho

Jr.- Júnior

Mai.- Maio

MG- Minas Gerais

MP- Ministério Público

$\mathrm{N}^{\mathrm{o}}$ - Número 
Nov.- Novembro

OAB- Ordem dos Advogados do Brasil

Out.- Outubro

P. - Página

PCA- Procedimento de Controle Administrativo

Rel.- Relator

REsp- Recurso Especial

RHC- Recurso em Habeas Corpus

RJ- Rio de Janeiro

RMS- Recurso em Mandado de Segurança

SC- Santa Catarina

Set.- Setembro

STF - Supremo Tribunal Federal

STJ - Superior Tribunal de Justiça

SP- São Paulo

S.p.- Sem página

TJ - Tribunal de Justiça

TJSC- Tribunal de Justiça de Santa Catarina

TJRJ- Tribunal de Justiça do Rio de Janeiro

TJRS- Tribunal de Justiça do Rio Grande do Sul

V.g- Verbi Gratia

Vol.- Volume 


\section{INTRODUÇÃO}

O trabalho em questão possui o intuito de analisar os aspectos polêmicos nos julgamentos feitos pelo Tribunal do Júri, situações essas que são capazes de ensejar a existência de veredictos contestáveis e dubitáveis, a partir da lógica constitucional fundada no sistema acusatório e, portanto, de caráter democrático.

Busca-se vislumbrar, doravante, com o estudo em sede de Direito Comparado, somado a percepções de doutrina acerca do tema, de que forma os simbolismos e as próprias regras procedimentais do referido instituto, bem como os aspectos externos ao julgamento são capazes de exercer poder de influência na tomada de decisão pelo corpo de jurados.

Serão analisados, nesse contexto, o quantum de julgadores constantes no Conselho de Sentença e as decisões por maioria simples, com o objetivo de reflexão acerca da segurança jurídica proporcionada em tais veredictos; a proibição de deliberação entre os jurados, no sentido de ser ponderado o acerto ou atraso do legislador em manter a previsão da incomunicabilidade; a quebra da imparcialidade do Conselho de Sentença e o sistema da íntima convicção como aspectos que obstam o direito a um julgamento imparcial e, por fim, o posicionamento simbólico do membro do Ministério Público nas Sessões Plenárias como um fator interveniente nos veredictos proferidos pelo jurados.

Diante disso, é mister, para tanto, uma breve exposição do histórico do Tribunal do Júri, seja no contexto das teorias de sua concepção, seja na perspectiva da evolução do instituto no direito pátrio.

Além disso, devem ser objeto de destaque os princípios constitucionais do Tribunal Popular, os quais revelam tamanha importância e prestígio 
conferidos pelo constituinte originário ao instituto em análise. São eles: plenitude de defesa, soberania dos veredictos, sigilo das votações e competência para o julgamento dos crimes dolosos contra a vida. 


\section{CAPÍTULO I- BREVE HISTÓRICO DO TRIBUNAL DO JÚRI}

Não se pode afirmar, de forma precisa, o local e momento histórico nos quais o Tribunal do Júri veio à existência. Há correntes que defendem que tal instituição nasceu na Palestina, Grécia, Roma Antiga, Inglaterra ou até mesmo na época mosaica.

De acordo com o entendimento que interpreta a Palestina como o berço do instituto, o Tribunal do Júri teria sido criado a partir do Tribunal dos Vinte e Três, existente nas localidades cujo número de famílias superasse 120. Sua atribuição era o julgamento de casos criminais que ensejassem aplicação de pena de morte.

Segundo a corrente que defende o surgimento nos tempos de Moisés, afirma-se que o Tribunal do Júri foi criado entre os judeus no Egito. No sistema político local, os juízes encontravam-se vinculados aos ditames sacerdotais, figura que representava autoridade na sociedade judaica. Assim, tratava-se de um sistema teocrático.

Com o nascimento da Lei de Moisés (também conhecida como Os Dez Mandamentos), os cidadãos tornaram-se interessados nos julgamentos de casos pelos Tribunais à época. Nesse contexto, para aqueles que defendem a origem da instituição do Júri na época mosaica, era o momento em que surgiam suas bases, especialmente levando-se em conta o critério da oralidade. O julgamento, então, era feito pelo Conselho dos Anciãos, invocando-se o nome de Deus.

Por outro lado, consoante outra vertente doutrinária, a origem do Júri é verificada em Roma, na figura dos judices jurati. Estes, por sua vez, eram os jurados da época, que se manifestavam nos julgamentos pela absolvição, condenação ou até mesmo abstenção. $\mathrm{O}$ resultado deveria ser em decisão 
absoluta; no caso de haver empate, o acusado era absolvido. Se a maioria fosse verificada em votos de abstenção, as discussões e debates do caso concreto seriam retomadas para novas votações.

No entendimento de outra corrente, cujo local de origem se daria na Grécia, atribui-se importância à figura dos diskatas e centeni comites, como eram conhecidos estes últimos pelos germânicos. Assim, na Grécia, o sistema jurisdicional era dividido em dois Conselhos: Heliéia, cuja competência era limitada a casos de menor repercussão, e Aereópago, competente para o julgamento de homicídios premeditados.

Em que pese tais posicionamentos doutrinários, a corrente majoritária sustenta que a origem do Tribunal do Júri, tal qual se verifica nos dias de hoje, é constatada na Inglaterra, após o chamado IV Concílio de Latrão, que extinguiu as ordálias, no ano de 1215. Estas últimas, por sua vez, eram denominadas o judicium Dei (juízo de Deus), uma espécie probatória de fundamento religioso, utilizada nos julgamentos com o intuito de comprovar a culpa ou inocência do acusado.

Nesse contexto, após a extinção das referidas ordálias, é instituído na Magna Carta inglesa o Conselho de Jurados, fato que importaria, assim, no surgimento da instituição do Tribunal do Júri. Sobre o assunto, consoante as lições de Lenio Luiz Streck:

"Muito embora se possa falar da existência do júri na antiguidade, é na Magna Carta inglesa que ele aparece com mais especificidade, servindo de modelo para o mundo. Talvez por isso o júri se mantenha com mais prestígio nos países da common law, mormente nos Estados Unidos" (Streck, 2001, p.75/76).

Em suma, tais controvérsias a respeito do local geográfico onde teria se originado o Tribunal do Júri ocorrem em razão da ausência de documentação histórica suficiente, visto que tal instituto está ligado a povos remotos, o que compromete sua investigação temporal. 
O primeiro marco de previsão legal do Tribunal do Júri no Brasil deu-se por meio da Lei 18 de junho de 1822, que estabeleceu a competência para o referido instituto em matéria de crimes de imprensa. $\mathrm{O}$ corpo de jurados era composto por 24 homens, cidadãos (logo, eleitores), de reputação ilibada, bons, inteligentes e patriotas.

Isso denota o caráter elitista e abastado do corpo de jurados, representado pela classe econômica de alto poder aquisitivo da época. Nesse sentido, afirma Paulo Rangel:

"Se a pessoa podia ser jurada, ela podia ser eleitora; se ela era eleitora, ela podia ser jurada. Nasce aí a distância entre os jurados e os réus. Os réus nem sempre eram eleitores, mas pessoas das camadas mais baixas da sociedade, muitas daquelas que depois se passaria a chamar de excluídos sociais ou, na linguagem de Dussel, as vítimas. Logo, integrar o júri era algo possível apenas para determinada classe social, fazendo falecer de legitimidade a formação do conselho de sentença" (Rangel, 2018, p.71).

Na primeira Constituição do Brasil, outorgada por d. Pedro I no ano de 1824, o Tribunal do Júri foi reconhecido como um órgão do poder Judiciário, cuja competência versava sobre causas cíveis e criminais. Percebe-se, doravante, que fora conferida maior importância ao referido instituto, visto que a Lei 18 de junho de 1822 o restringia apenas aos julgamentos relacionados a crimes de imprensa.

Nesse sentido, assim previa a diç̧ão do art. 151 da Constituição de 1824 do Brasil Império: "O Poder Judicial é independente e será composto de juízes e jurados, os quais terão lugar assim no cível como no crime, nos casos e pelo modo que os Códigos determinarem."

Além disso, complementava o art. 152 da referida Carta Magna: "Os jurados pronunciam sobre o fato e os juízes aplicam a lei."

Outra importante inovação legal referente à evolução do Tribunal do Júri no Brasil foi a entrada em vigor do Código de Processo Criminal em 1832. 
Tal diploma legal realizava a distinção entre o "grande júri", formado por 23 (vinte e três) membros e o "pequeno júri”, cuja composição agregava 12 (doze) membros. O primeiro era responsável pela análise de procedência da acusação, isto é, o momento do juízo de sua admissibilidade, ao passo que o "pequeno júri”, caso houvesse procedência da acusação, estaria incumbido de julgar o caso em questão.

Acerca da composição do Tribunal do Júri à luz do Código de Processo Criminal de 1832, observa José Frederico Marques:

"Pelo sistema do Código de 1832, em cada distrito havia um juiz de paz, um escrivão, inspetores de quarteirão e oficiais de Justiça; nos termos, um Conselho de Jurados, juiz municipal, promotor público, escrivão das execuções e oficiais de justiça; nas comarcas, um juiz de direito, ou mais, conforme a população (...) Havia dois conselhos de jurados, sendo o primeiro conselho, ou Júri de acusação, composto de vinte e três jurados e o segundo, ou Júri de sentença, de doze” (Marques, 1997, p. 39).

Com a promulgação da Constituição de 1891, o Tribunal do Júri foi previsto no Título IV, intitulado "Dos cidadãos brasileiros", na Seção II, referente a "Declaração de Direitos" que, na dicção do art. 72, §31, assim afirmava: "será mantida a instituição do jury". Em razão de tal norma constitucional, sustentou-se que, no caso de serem editadas leis cujo conteúdo alterasse a essência já consolidada do Tribunal do Júri, estas seriam tidas por inconstitucionais.

Além disso, após a proclamação da República, criou-se o instituto do júri federal, por meio do Decreto 848 de 11 de outubro de 1890, formado por 12 (doze) jurados, sorteados em um universo de 36 (trinta e seis) cidadãos.

A Carta de 1934, por sua vez, eliminou o status de "Declaração de Direitos" do qual o Tribunal do Júri era revestido na Constituição de 1891. Antes da promulgação da Carta de 1934, porém, fora expedido o Decreto ${ }^{\circ}$ 24.776, que versava sobre a liberdade de imprensa, estabelecendo que o júri seria formado pelo reduzido número de 4 cidadãos. 
De outra sorte, Constituição outorgada de 1937 silenciou a respeito da existência do Tribunal Popular. Parte dos estudiosos defende que isso ocorreu em função do governo ditatorial estabelecido por Getúlio Vargas, o que transformava o Direito Penal em uma fonte de punição, e não uma garantia de direitos em face do poder do Estado.

Entretanto, na data de 5 de janeiro de 1938, foi promulgado o decreto-lei 167, que apresentou relevantes mudanças e alterações na instituição do Tribunal do Júri, como, por exemplo, a supressão da soberania dos veredictos. Isso porque passou a existir a possibilidade de a decisão meritória (condenação ou absolvição do acusado) ser reformada em âmbito recursal, pelo Tribunal de Apelação, quando houvesse "injustiça da decisão" ou "completa divergência" em relação ao conteúdo probatório produzido em âmbito processual.

Dessa forma, o critério para reforma da decisão era fundado em um conceito jurídico indeterminado, de modo que o intérprete teria, em suas mãos, o poder de vislumbrar ou não eventual hipótese de reforma da decisão.

Sobre o assunto, preleciona Paulo Rangel:

"Na medida em que o regime é endurecido, o governante precisa intervir no Poder Judiciário dificultando a liberdade e facilitar a repressão com a consequente privação das liberdades públicas. O Estado passa a se constituir em Estado punitivo e não, como deveria ser, Estado de bem-estar social. O Direito Penal passa a ser usado como instrumento de defesa do chamado bem jurídico, ante possíveis lesões ou perigos. O Tribunal de Apelação, na época, sofria fortes influências do ditador Vargas, que exercia controle sobre ele. Por isso, o júri era manipulado pelo exercício abusivo do poder, perdendo sua origem de tribunal popular, democrático, criado para retirar das mãos do déspota o poder de decisão sobre a vida dos súditos" (Rangel, 2018, p. 82).

Tal modificação substancial no instituto do Júri foi objeto tanto de contundentes críticas pela comunidade jurídica à época, quanto de aplausos e aprovações. Nestes termos, aponta José Frederico Marques: 
"Nos meios forenses, houve muita gritaria contra a inovação. Alegou-se que o Decretolei $n^{\circ} 167$, o que fez, 'regulando a instituição do Júri, foi praticamente abolir o Júri'. Outros, embora não condenassem a reforma havida, viam nela a 'morte virtual do instituto do Tribunal dos Jurados'. E isto sem falar nos que atribuíam a lei ao caráter antidemocrático do novo regime. Vozes, entretanto, não faltaram, para elogiar a inovação, nela enxergando um meio eficacíssimo de coibir os abusos do Tribunal do Júri” (Marques, 1997, p.51/52).

Já a Carta de 1946, de outra sorte, retomou a previsão do Júri, em seu art. 141, §28º constante no Título IV "da Declaração de Direitos", Capítulo II "dos Direitos e das Garantias Individuais"- foi responsável por normatizar, com assento constitucional, o sigilo das votações, a plenitude de defesa do réu e a soberania dos veredictos. Além disso, estabeleceu que sua competência era referente aos crimes dolosos contra a vida.

No tocante à Constituição de 1967, manteve-se a existência do Tribunal do Júri, diferentemente da Carta de 1937, que não o previu em sua redação. Assim, a referida Carta do período de ditadura militar manteve o Júri no capítulo referente aos "Direitos e Garantias Individuais", em seu art. 150, $\S 18$, silenciando apenas a respeito do sigilo das votações, plenitude de defesa do réu e a soberania dos veredictos.

Finalmente, em 1988, foi promulgada a Constituição Cidadã, que preservou a ideia de que a instituição do Júri era tida como uma garantia individual do cidadão de ser julgado por seus semelhantes. Nestes termos, dispõe, em seu art. $5^{\circ}$, XXXVIII a competência para o julgamento dos crimes dolosos contra a vida, bem como as garantias referentes à plenitude de defesa, sigilo das votações e soberania dos veredictos.

Portanto, é possível constatar que a história constitucional reflete importante evolução do instituto do Tribunal Popular, na tentativa de que sua composição, garantias e procedimentos se tornassem, ao longo do tempo, envoltos pelo manto da democracia. 
Um aspecto que comprova tal tentativa de democratização do Tribunal do Júri é a evolução dos requisitos para a composição do Conselho de Sentença, isto é, na exigência de atributos para que o indivíduo exercesse a atribuição de jurado. O Código de Processo Criminal do Império previa que deveriam ser escolhidos cidadãos que oferecessem inteligência no desempenho da função, bem como conduta ilibada e de acordo com a moral e os bons costumes. Sobre o assunto, afirma Paulo Rangel:

\footnotetext{
"Nesse sentido, não há dúvida do caráter democrático da instituição do Tribunal do Júri que nasce, exatamente, das decisões emanadas do povo, retirando das mãos dos magistrados comprometidos com o déspota o poder de decisão. Fato que, posteriormente, com a formação do Tribunal Júri, no Brasil, feita por pessoas que gozassem de conceito público por serem inteligentes, íntegras e de bons costumes (cf. art. 27 do Código de Processo Criminal do Império - Lei de 29 de novembro de 1832), faz estabelecer um preconceito social e, embora disfarçada, uma luta entre classes" (Rangel, 2018, p.54).
}

Ora, é inconteste que se tratava de um filtro elitista para a escolha de jurados, ou seja, despido de princípios plurais e democráticos. Atualmente, os requisitos para composição do júri não impõem qualquer exigência nesse sentido; basta que seja uma (um) cidadã (o) que esteja em pleno gozo de direitos políticos (ser eleitor), não tenha sido processado criminalmente e que preste o serviço de forma gratuita.

Nestes termos, segundo as lições de José Frederico Marques, o Tribunal do Júri, à luz do ordenamento jurídico pátrio, é considerado um órgão judiciário integrante da Justiça Comum (entendimento majoritário), caracterizado por ser integrado por um colegiado heterogêneo, visto que há 1 (um) juiz togado e 25 (vinte e cinco) jurados leigos como membros do referido órgão. Além disso, possui caráter temporário, já que é formado, especificamente, para uma Sessão de Julgamento, de modo que, uma vez encerrada, resulta na dissolução de tal colegiado.

Guilherme de Souza Nucci acompanha o entendimento supracitado, ao lecionar que: 
"Majoritariamente, entende-se ser o júri órgão do Judiciário, embora lhe seja reconhecida a especialidade. Não consta do rol do art. 92 da Constituição Federal, embora o sistema judiciário o acolha em outros dispositivos, tornando-o parte integrante do Poder Judiciário" (Nucci, 2015, p.680). 


\title{
CAPÍTULO II- PRINCÍPIOS CONSTITUCIONAIS DO TRIBUNAL DO JÚRI
}

\subsection{Considerações preliminares}

\begin{abstract}
"Dentro do universo jurídico, os princípios soam como algo sagrado, vez que considerados como proposições normativas pertencentes a uma dimensão mais elevada, com a importante missão, de aferirem, inclusive, a pertinência do regramento constitucional. Pois bem, se os princípios estão a informar o conteúdo da Lei Maior, é evidente que se constituem como importante ferramenta de interpretação da elaboração e aplicação das normas de conteúdo infraconstitucional" (Guimarães \& Silva, 2012, p.397).
\end{abstract}

A instituição do Tribunal do Júri, nesse sentido, apresenta quatro princípios dotados de status constitucional, uma vez previstos pelo próprio poder constituinte originário de 1988.

Em seu art. 50, XXXVIII, alíneas “a)”, “b)”, “c)” e “d)”, a Lei Maior prevê, respectivamente, os seguintes princípios do Júri: a plenitude de defesa, o sigilo das votações, a soberania dos veredictos e a competência para o julgamento dos crimes dolosos contra a vida.

Acerca da instituição do Tribunal do Júri, assevera Guilherme de Souza Nucci:

"Situado no contexto dos direitos e garantias humanas fundamentais, convém explicitar qual seria realmente a posição constitucional do Tribunal Popular. Considerando-se direito individual aquele que declara situação inerente à personalidade humana (ex: vida, liberdade, integridade física) e garantia individual aquela cuja finalidade é assegurar que o direito seja, com eficácia, fruído, observa-se, majoritariamente, na doutrina ser o júri uma garantia (...) Entendemos, também, ser o Tribunal do Júri, primordialmente, uma garantia individual. Mas, pergunta-se: garantia a quê? Muitos têm sustentado, a nosso ver equivocadamente, ser uma garantia ao direito de liberdade. Fosse assim, teríamos que admitir ser o júri um escudo protetor do criminoso, que 
atenta contra a vida humana, o que não pode ser admissível. Além disso, é preciso destacar ser o direito à vida igualmente protegido na Constituição- tanto quanto o direito à liberdade-, de forma que o júri não poderia proteger um, em prejuízo do outro. A vida da vítima foi eliminada pelo réu e o Tribunal Popular não tem por fim proteger ou garantir fique o acusado em liberdade (...) Por outro lado, não deixamos de visualizar no júri, em segundo plano, mas não menos importante, um direito individual, consistente na possibilidade que o cidadão de bem possui de participar, diretamente, dos julgamentos do Poder Judiciário. Em síntese: O júri é uma garantia individual, precipuamente, mas também um direito individual. Constitui cláusula pétrea na Constituição Federal (cf. art. 60, §4 $4^{\circ}$, IV)" (Nucci, 2015, p.679/680).

Percebe-se, diante disso, que o Tribunal do Júri, segundo a lógica constitucional vigente, assume o papel de garantia fundamental, haja vista ter sido previsto pelo constituinte originário no art. $5^{\circ}$ da Carta de 1988. Tratase de um direito fundamental por prever a possibilidade de o acusado ser julgado por seus pares, embora não seja um viés de entendimento unânime pela doutrina (haja vista a citação supra), bem como por garantir a atuação popular no âmbito do poder Judiciário.

Assim, diante dessa análise, o referido instituto visa realizar, primordialmente, os valores democráticos e garantistas estabelecidos pela Constituição Cidadã de 1988.

\subsection{Plenitude de defesa}

Em um primeiro momento, mister se faz a diferenciação entre "plenitude de defesa" e "ampla defesa". Esta última é garantia de todo e qualquer acusado, seja em processo judicial, seja em processo administrativo, consoante a dicção do art. $5^{\circ}$, LV da Constituição Federal.

De outra sorte, a plenitude de defesa é um direito previsto especificamente para os acusados submetidos ao Tribunal do Júri, garantia está disposta pelo art. $5^{\circ}$, XXXVIII, alínea "a)" da Constituição Federal. Nesse sentido, afirma Renato Brasileiro de Lima: 
"Há quem entenda que não há diferença substancial entre ampla defesa e plenitude de defesa. A nosso juízo, porém, a plenitude de defesa implica no exercício da defesa em um grau ainda maior do que a ampla defesa, compreendendo dois aspectos distintos: a plenitude da defesa técnica e a plenitude da autodefesa" (Lima, 2015, p.1314).

A plenitude da defesa técnica consiste na maior ampliação dos meios de defesa pelo patrono da causa, que não se encontraria adstrito a fundamentos meramente jurídicos. Assim, comumente se verificam sustentações de advogados perante o Tribunal do Júri cuja fala é embasada em outras áreas do saber, como é o exemplo da Psicologia, Sociologia, e até mesmo argumentos de cunho emocional (também conhecido como clemência), dentre outros.

Um curioso caso concreto ilustra de forma palpável a aplicação da plenitude da defesa técnica: trata-se do julgamento de Iara Marques Barcelos, que fora acusada de, no município de Itapuã, localizado no estado do Rio Grande do Sul, contratar o corréu Leandro da Rocha Akneida, mediante promessa de recompensa, para executar a vítima Ercy da Silva Cardoso.

Durante a Sessão Plenária de julgamento, a defesa técnica de Iara Marques valeu-se de uma carta psicografada em que a própria vítima, Ercy da Silva, inocentava a ré.

A acusada fora absolvida pelo Tribunal Popular no quórum de 5 votos em seu favor em face de 2 no sentido de condenação, decisão que fora objeto de recurso de apelação por parte da assistência de acusação, que sustentou, dentre outros argumentos, $\mathrm{o}$ fato de que a carta psicografada era falsa.

Diante da interposição do recurso de apelação, manifestou-se o TJRS no sentido de admitir a licitude da carta psicografada como meio de prova no referido caso concreto:

“JÚRI. DECISÃO ABSOLUTÓRIA. CARTA PSICOGRAFADA NÃO CONSTITUI MEIO ILÍCITO DE PROVA. DECISÃO QUE NÃO SE MOSTRA 
MANIFESTAMENTE CONTRÁRIA À PROVA DOS AUTOS. Carta psicografada não constitui meio ilícito de prova, podendo, portanto, ser utilizada perante o Tribunal do Júri, cujos julgamentos são proferidos por íntima convicção. Havendo apenas frágeis elementos de prova que imputam à pessoa da ré a autoria do homicídio, consistentes sobretudo em declarações policiais do co-réu, que depois delas se retratou, a decisão absolutória não se mostra manifestamente contrária à prova dos autos e, por isso, deve ser mantida, até em respeito ao preceito constitucional que consagra a soberania dos veredictos do Tribunal do Júri. Apelo improvido."

(TJRS, $1^{\text {a }}$ Câmara Criminal, Apelação nº70016184012, Rel. Desembargador Manuel José Martinez Lucas, Porto Alegre, 11 nov. 2009)

No tocante à plenitude da autodefesa, isso também importa no fato de que ao acusado deve ser assegurada a garantia de liberdade em apresentar sua versão no momento do interrogatório, no sentido de ir ao encontro de seus interesses. Assim, o acusado tem direito, no momento da elaboração dos quesitos, de ser vislumbrada a sua versão dada no momento do interrogatório.

Nesse sentido, já houve manifestação do Superior Tribunal de Justiça:

"RECURSO ESPECIAL. PENAL E PROCESSUAL PENAL. HOMICÍDIO QUALIFICADO. DIVERGÊNCIA NÃO COMPROVADA. TRIBUNAL DO JÚRI. PLENITUDE DE DEFESA. ART. 482 DO CÓDIGO DE PROCESSO PENAL. RÉU NÃO APRESENTOU TESE DE LEGÍTIMA DEFESA. NULIDADE. INEXISTÊNCIA. IRREGULARIDADE NA QUESITAÇÃO. MOMENTO OPORTUNO APÓS AS EXPLICITAÇÕES DO JUIZ-PRESIDENTE. PRECLUSÃO.

1. A sugerida divergência não foi demonstrada na forma preconizada nos arts. 541, parágrafo único, do Código de Processo Civil e 255, $\S ~ 1 .^{\circ}$ e $2 .^{\circ}$, do Regimento Interno do Superior Tribunal de Justiça.

2. O direito à plenitude de defesa é garantido aos Réus submetidos ao Tribunal do Júri, cabendo ao magistrado incluir no questionário tese levantada pelo Réu no momento de seu interrogatório, ainda que não apresentada pela defesa técnica, sob pena de nulidade, nos termos do art. 484, inciso III, do Código de Processo Penal (com redação anterior à vigência da Lei n. $.^{\circ} 11.689 / 2008$ ) e por força do art. 482, parágrafo único, do referido estatuto.

3. No entanto, no caso em comento, não se observa do interrogatório do Réu qualquer tese relativa à legítima defesa, o que afasta a impugnação de nulidade por ausência de quesito obrigatório. 
4. Hipótese em que as demais alegações relativas à formulação dos quesitos constituiriam mera irregularidade sem aparente prejuízo para a defesa e, como não foram suscitadas no momento oportuno, tornaram-se preclusas.

5. Recurso parcialmente conhecido e, nessa parte, desprovido."

(STJ, Quinta Turma, Recurso Especial $n^{\circ} 737824 / C E$, Rel. Ministra Laurita Vaz, Brasília, 19 de nov.2009)

\title{
2.3. Sigilo das votações
}

Tal garantia encontra-se prevista pelo art. $5^{\circ}$, XXXVIII, alínea "b)" da Constituição Federal. No Brasil, a regra de julgamento é o livre convencimento motivado, o qual encontra assento constitucional no art. 93, IX da Carta de 1988, no Capítulo III, intitulado "do Poder Judiciário".

No sistema do livre convencimento motivado, as decisões judiciais devem ser fundamentadas, sob pena de nulidade. Isso porque, no âmbito do Estado Democrático de Direito, as noções de poder não podem ser justificativas para que sejam cometidos atos arbitrários por parte do Estado.

Assim, a fundamentação serve como um verdadeiro limite e fiscalização de possíveis arbítrios praticados pelo poder estatal. Nesse sentido, preleciona Renato Brasileiro de Lima:

\begin{abstract}
"Com o passar do tempo, a garantia da motivação das decisões passou a ser considerada também garantia da própria jurisdição. Afinal de contas, os destinatários da fundamentação não são mais apenas as partes e o juízo ad quem, como também toda a coletividade que, com a motivação, tem condições de aferir se o magistrado decidiu com imparcialidade a demanda. Muito além de uma garantia individual das partes, a motivação das decisões judiciais funciona como exigência inerente ao próprio exercício da função jurisdicional. Não por outro motivo, a garantia da motivação vem prevista na Constituição Federal no capítulo pertinente ao Poder Judiciário, e não no capítulo de direitos e garantias individuais, em que se encontra grande parte das garantias processuais. Destarte, sob o enfoque da sociedade, pode-se dizer que a motivação também apresenta uma relevância extraprocessual” (Lima, 2015, p.1482).
\end{abstract}

No entanto, no tocante ao procedimento do Tribunal do Júri, o sistema do livre convencimento motivado não é aplicável ao Conselho de Sentença. 
Trata-se, pois, de uma exceção prevista pelo próprio constituinte originário, no dispositivo outrora mencionado. Isso porque, considerando a composição leiga do referido Conselho, o poder constituinte originário atentou-se em preservar a imparcialidade dos jurados, no sentido de evitar represálias ou até mesmo votos já previamente "combinados".

Assim, no Tribunal do Júri verifica-se o sistema da íntima convicção, no qual os jurados não fundamentam suas respostas aos quesitos. Nessa matéria, manifesta-se Renato Brasileiro de Lima:

\begin{abstract}
"Se a fundamentação funciona como regra geral para a prolação de uma sentença, não se pode negar que, no âmbito do Tribunal do Júri, as decisões dos jurados não precisam ser motivadas. Isso porque, de acordo com o art. $5^{\circ}$, inciso XXXVIII, da Magna Carta, tem-se como uma das garantias do júri o sigilo das votações. Ou seja, fosse o jurado obrigado a fundamentar sua decisão, seria possível identificar-se o sentido de seu voto. Daí a desnecessidade de fundamentação do voto do jurado, limitando-se o mesmo a um singelo "sim" ou "não" para cada quesito que lhe for formulado, nos exatos termos do art. 486, caput, do CPP” (Lima, 2015, p.603).
\end{abstract}

Como desdobramento desta garantia, verifica-se a previsão legal da chamada sala especial, disposta pelo art. 485, caput do Código de Processo Penal, cuja razão de ser é preservar o sigilo das votações do Conselho de Sentença. De acordo com a diç̧ão do parágrafo único do mesmo artigo, na falta de sala especial, o juiz presidente determinará que os presentes se retirem, com exceção dos jurados, Ministério Público, assistente, querelante, defensor do acusado, escrivão e oficial de justiça.

Importante discussão nesse sentido é com relação à compatibilidade da sala secreta em face do princípio da publicidade. Segundo a dicção do art. $5^{\circ}$, inciso XXXVIII, alínea “b)”, deve ser assegurado o "sigilo das votações", de modo que parte da doutrina, de forma minoritária, entendia que a preposição "das" abrangia tão somente o sigilo do conteúdo dos votos. Assim, consoante este entendimento, não haveria razão de ser da sala secreta, uma vez que o sigilo a que se refere o constituinte originário é em relação ao sentido do voto proferido por cada jurado. 
No entanto, a corrente doutrinária que prevaleceu é no sentido de que não

há falar em incompatibilidade da sala secreta com o princípio da publicidade.

Em outras palavras, a existência da sala secreta não ofende o princípio constitucional da publicidade. Nesse diapasão, preleciona Guilherme de

Souza Nucci:

"Em primeiro lugar, deve-se salientar ser do mais alto interesse público que os jurados sejam livres e isentos para proferir seu veredicto. Não se pode imaginar um julgamento firme, longe de qualquer pressão, feito à vista do público, no plenário do júri. Note-se que as pessoas presentes costumam manifestar-se durante a sessão, ao menor sinal de um argumento mais incisivo feito pela acusação ou pela defesa. Ainda que o juiz exerça o poder de polícia na sala e possa determinar a retirada de alguém espalhafatoso de plenário, é certo que, durante a votação, essa interferência teria consequências desastrosas. Imagine-se um julgamento perdurando por vários dias, com todos os jurados exaustos e a votação final sendo realizada à vista do público em plenário. Se uma pessoa, não contente com o rumo tomado pela votação, levantar-se e ameaçar o Conselho de Sentença, poderá influir seriamente na imparcialidade do júri, ainda que seja retirada- e até presa- por ordem do juiz presidente. Anular-se-ia um julgamento tão custoso para todos, por conta dessa invasão no convencimento dos juízes leigos? Justamente porque os jurados não detêm as mesmas garantias- nem o mesmo preparoda magistratura togada, idealizou o legislador, com acerto, a sala especial. Não é secreto o julgamento, pois acompanhado pelo promotor, pelo assistente de acusação, pelo defensor e pelos funcionários do Judiciário, além de ser comandado pelo juiz de direito (...) Ademais, há na própria Constituição o disposto no art. $5^{\circ}$, XXXVIII, $b$, assegurando o sigilo das votações. Não se fala em sigilo do voto, entendido como a cédula individual colocada pelo jurado, contendo "sim" ou "não", dentro da urna, mas em sigilo da votação, que é o ato de votar. Portanto, busca-se resguardar o momento do jurado opor o voto na urna- que é votar-, razão pela qual a sala especial é o lugar ideal para tanto. Não se tem notícia de Tribunal do Júri no mundo que proporcione aos jurados a votação em sala aberta, à vista do público. Rui Barbosa sempre considerou o sigilo da votação algo essencial à instituição do júri, o que é posição francamente majoritária atualmente. Por todos, veja-se Hermínio Alberto Marques Porto: "Tais cautelas da lei visam a assegurar aos jurados a livre formação de sua convicção e a livre manifestação de suas conclusões, afastando-se quaisquer circunstâncias que possam ser entendidas, pelos julgadores leigos, como fontes de contrangimento. Relevante é o interesse em resguardar a formação e a exteriorização da decisão" (Nucci, 2015, p.740/741).

Nessa linha, compartilha o mesmo entendimento Renato Brasileiro de Lima:

"Ora, em se tratando de votação no tribunal do júri, deve-se ter em mente que a própria Constituição Federal assegura o sigilo das votações (CF, art. $5^{\circ}$, XXXVIII, "b"). Além disso, há de se lembrar que jurados são cidadãos leigos, pessoas comuns do povo, magistrados temporários, que não gozam das mesmas garantias constitucionais da magistratura, daí por que poderiam se sentir intimidados com a presença do réu e de populares se acaso a votação se desse perante eles, afetando-se a necessária e imprescindível imparcialidade do julgamento. Cuida-se, pois, de restrição legal 
justificada pelo interesse público de assegurar a tranquilidade dos jurados no momento da votação. Evidente, pois, a compatibilidade da sala secreta com o princípio da publicidade, ainda mais se considerarmos que a colheita de provas, os debates e a leitura da sentença são feitos publicamente no recinto do Tribunal do Júri” (Lima, 2015, p.1316)

Além disso, relevante consequência da garantia do sigilo das votações, segundo entendimento majoritário, é a incomunicabilidade dos jurados. Diante disso, não é possível o debate sobre o caso em questão entre os membros do Conselho de Sentença, que deve permanecer incomunicável enquanto a sessão de julgamento não encerrar. Nestes termos, a ofensa à incomunicabilidade dos jurados importa em nulidade absoluta, consoante a norma extraída do art. 564, III, alínea “j)” do Código de Processo Penal.

Portanto, Sessões Plenárias que perdurem por dias devem observar a norma do art. 497, VIII do Código de Processo Penal, com intuito de preservar a referida incomunicabilidade. Esse é o motivo pelo qual devem ser providas habitações para os jurados, no caso de a Sessão prolongar-se por dias, já que os mesmos não podem ter contato com o mundo exterior durante a apreciação do caso.

Por fim, mister é a constatação da alteração feita pela Lei 11.686/08 na forma pela qual se realiza o cômputo dos votos proferidos pelos jurados. Com a sua entrada em vigor, passou a dispor o art. $483, \S 1^{\circ}$ do Código Penal que a contagem de mais de 3 (três) respostas negativas em relação à materialidade do fato ou autoria/participação importa no encerramento da votação.

Logo, tal norma visa a proteção do sigilo das votações na medida em que interrompe a contagem dos votos, automaticamente, quando houver 4 (quatro) votos em um determinado sentido. Doravante, se houver votos unânimes $(7 \mathrm{x} 0)$, por exemplo, o cômputo dar-se-á por encerrado quando forem contabilizados 4 (quatro) votos, impedindo, pois, que seja conferida publicidade à orientação do voto de cada um dos jurados. 
Sobre o assunto, ensina Paulo Rangel:

"Há uma enorme confusão entre a incomunicabilidade e o sigilo do voto. O sigilo visa evitar que se exerça pressão sobre a votação dos jurados, seja com perseguições, ameaças, chantagens, vantagens ou qualquer outro expediente que possa perturbar a livre manifestação do conselho de sentença. Contudo, para que se possa, realmente, assegurar o sigilo da votação, mister se faz que a contagem dos votos cesse no quarto voto sim, ou no quarto voto não, conforme o caso, pois na medida em que o juiz presidente do júri permite que sejam retirados todos os (sete) votos da urna é possível, como ocorre, que haja unanimidade de votos e, nesse caso, não será difícil adivinhar quem condenou (ou absolveu) o réu. Logo, por terra foi a garantia constitucional do sigilo dos votos (...) Entretanto, fala-se da incomunicabilidade, da ausência de expressão verbal entre os jurados na hora do julgamento, no momento em que a liberdade do outro está sendo decidida entre aqueles que o chamam de seus pares. $4 \mathrm{~A}$ incomunicabilidade assegurada na lei é "para que o jurado decida por si, sem influência estranha" (Rangel, 2018, p.87-89).

\subsection{Soberania dos veredictos}

$\mathrm{Na}$ sequência de garantias constitucionais a respeito da instituição do Tribunal do Júri, há a soberania dos veredictos, cuja previsão constitucional é no art. 5 $5^{\circ}$, XXXVIII, alínea “c)". Seu valor normativo importa no fato de que as decisões proferidas pelo Conselho de Sentença não podem ser substituídas por órgão colegiado, em grau recursal, no que tange ao mérito.

Logo, se um indivíduo é condenado em $1^{\mathrm{a}}$ instância pelo Tribunal do Júri, não há falar em reforma da decisão pelo juízo ad quem no sentido de absolver o acusado ou mesmo condená-lo, isto é, no sentido de apreciar o mérito do caso.

Nestes termos, ressalta Renato Brasileiro de Lima:

"É necessário que se distinga, então, na sentença subjetivamente complexa do júri, qual matéria é de competência dos jurados- e, por conseguinte, acobertada pela soberania dos veredictos- e qual matéria é de competência do juiz presidentedesprovida, pois do atributo da soberania. Aos jurados compete decidir sobre a existência do crime e autoria delitiva, bem como em relação à presença de qualificadoras, causas de aumento e de diminuição de pena. Portanto, somente com relação à decisão de tais questões é que se pode falar em soberania dos veredictos. Lado outro, como a fixação da pena é matéria afeta à competência do juiz presidente, 
e não aos jurados, não há falar em impossibilidade de reforma da decisão" (Lima, 2015, p.1318)

Além disso, complementa José Frederico Marques:

"O problema se situa, assim, no campo da competência funcional. Sobre a existência de crime e responsabilidade do réu, só o Júri pode pronunciar-se, o que faz através de veredictos soberanos. Sobre a aplicação da pena, decide, não soberanamente, o juiz que preside ao Júri. Aos tribunais superiores, o objeto do juízo, na sua competência funcional, se restringe à apreciação sobre a regularidade do veredicto, sem o substituir, mas pronunciando ou não pronunciando o sententia rescindenda sit. No tocante à decisão do juiz togado, a competência funcional será de grau, podendo assim a jurisdição superior retificá-la (art. 593, $\left.§ 1^{\circ} \mathrm{CPP}\right)$ ” (Marques, 1997, p.80).

No entanto, a soberania dos veredictos não deve ser entendida de forma absoluta. Muito embora o juízo ad quem, em sede recursal, não esteja munido de atribuição (isto é, competência) para alterar o mérito da decisão proferida pelo Conselho de Sentença, é possível a anulação da Sessão Plenária realizada, de modo a submeter o acusado a um novo julgamento.

A hipótese narrada acima encontra fundamento legal no art. 593, III, alínea "d)" do Código de Processo Penal. Assim, nas situações em que a decisão dos jurados for manifestamente contrária à prova dos autos, o réu deverá ser submetido a um novo julgamento, segundo a inteligência do art. 593, $\$ 3^{\circ}$ do Código de Processo Penal.

No entanto, é mister ressaltar que tal sujeição a novo julgamento encontra limitações. Segundo a própria dicção do art. 593, $\$ 3^{\circ}$ do Código de Processo Penal, não é permitido, nesta lógica, que a Sessão Plenária de julgamento seja anulada mais de uma vez com fulcro no mesmo motivo, qual seja, por decisão dos jurados manifestamente contrária à prova dos autos.

Nestes termos, acerca da mitigação ou flexibilização do princípio da soberania dos veredictos, a Jurisprudência manifesta-se nos seguintes termos: 
CONTRADIÇÃO CONFIGURADAS. VIOLAÇÃO DO ART. 619 DO CPP. ACÓRDÃO QUE CRIA CONTRA LEGEM HIPÓTESE DE RECURSO EXCLUSIVO DA DEFESA. HOMICÍDIO SIMPLES. TRIBUNAL DO JÚRI. ABSOLVIÇÃO PELOS JURADOS DECORRENTE DE CONTRADIÇÃO ENTRE AS RESPOSTAS DOS QUESITOS.TESE DEFENSIVA LIMITADA À DESCLASSIFICAÇÃO DO DELITO, DE HOMICÍDIO DOLOSO PARA CULPOSO, TIPIFICADO NO ART. 302 DO CÓDIGO DE TRÂNSITO BRASILEIRO. JULGAMENTO MANIFESTAMENTE CONTRÁRIO À PROVA DOS AUTOS. VIOLAÇÃO DO ART. 593, III, "D", DO CPP. MITIGAÇÃO DO PRINCÍPIO DA SOBERANIA DO JÚRI. POSSIBILIDADE. PRECEDENTES DO STJ. SUBMISSÃO DO RÉU A NOVO JULGAMENTO PELO CONSELHO DE SENTENÇA. AGRAVO REGIMENTAL NÃO PROVIDO.

1. O acórdão que, a despeito de conter relevantes omissões na decisão atacada, não

acolhe os embargos declaratórios e limita-se a afirmar que a análise deles implicaria revisão das provas e deixa de sanar a contradição apontada, ao esquecer-se de enfrentar importantes fundamentos invocados pelo Ministério Público, cuja análise poderia, por si só, basear decisão diversa daquela exarada pelo órgão julgador, nega vigência aos arts. 619 e 620 do Código de Processo Penal.

(...)

6. A absolvição do réu pelos jurados, com base no art. 483, III, do CPP não constitui decisão absoluta e irrevogável. O Tribunal pode cassar tal decisão quando ficar demonstrada a total dissociação da conclusão dos jurados com as provas apresentadas em plenário.

7. Na hipótese, conforme se extrai do conjunto probatório, a defesa não pleiteou a absolvição por clemência e sua única tese limitou-se à desclassificação do delito, de homicídio doloso para culposo, tipificado no art. 302 do Código Brasileiro de Trânsito.

8. Agravo regimental não provido.”

(STJ, 6a Turma, AgRg no REsp 1415980/RS, Rel. Ministro Rogerio Schietti Cruz, Brasília, 25 jun. 2019)

\subsection{Da competência para o julgamento dos crimes dolosos contra a vida}

Segundo o dispositivo do art. $5^{\circ}$, XXXVIII, alínea "d" da Constituição Federal, o Tribunal do Júri possui competência para apreciar e julgar os crimes dolosos contra a vida, quais sejam- o crime de homicídio (art. 121, $\mathrm{CP}$ ), induzimento, instigação ou auxilio ao suicídio (art 122, CP), infanticídio 
(art. 123, CP) e abortamento (art. 124, art. 125 e art. 126, todos constantes no $\mathrm{CP})$. Registre-se que todos os referidos crimes encontram-se previstos no Título I do Estatuto Repressivo, que prevê os crimes contra a pessoa, em seu Capítulo I, o qual enumera os crimes contra a vida.

Outro dispositivo legal de suma importância no tocante à competência do Tribunal do Júri é o art. 74 do CPP, que ratifica o mandamento constitucional acerca da competência para julgamento dos crimes dolosos contra a vida.

Além da competência para o julgamento dos referidos crimes, o Tribunal do Júri é competente para julgar as infrações conexas. Segundo José Frederico Marques,

\begin{abstract}
"Diante de tal regra, dúvida não pode haver de que a competência do Júri é sempre prevalente, quando em confronto com a de outro órgão da justiça comum. E essa prevalência é absoluta, pois que fundada na competência ratione materiae. Daí resulta que, na esfera da justiça comum, desde que exista crime em conexão com outro da competência do Júri, tem este, de regra, competência para julgar a todos os delitos conexos; e em relação a todos deve o Tribunal do Júri funcionar com as características que lhe impõe a Constituição Federal. Desse modo, nos processos cumulativos que correm perante o Júri, a soberania dos veredictos é obrigatória não só para o julgamento dos crimes da competência privativa do Júri, como também para aqueles outros atraídos para a órbita de suas atribuições jurisdicionais, ratione connexitatis" (Marques, 1997, p.274)
\end{abstract}

Já foi tema de divergência jurisprudencial a questão do crime de latrocínio (art. 157, parágrafo $3^{\circ}$, inciso II do $\mathrm{CP}$ ) ser ou não ser de competência de julgamento pelo Tribunal do Júri. Acerca de tal controvérsia, ensina o professor José Frederico Marques, ressaltando os aspectos técnicos de seu entendimento:

\footnotetext{
"Segundo o Código Penal em vigor, são crimes contra a vida: o homicídio, o induzimento ou instigação ao suicídio, o infanticídio e o aborto. Fora, porém, do cap. I, tít. I, da parte especial, cuja rubrica qualifica os crimes definidos no capítulo de "crimes contra a vida", o Código Penal prevê vários crimes qualificados pelo evento morte (casos de homicídio preterdoloso) ou em que este configure como condição de maior punibilidade, ou resulta de violência empregada para assegurar a execução, impunidade ou vantagem de outro crime, como no caso de latrocínio (art. 157, §3º. Foi imposta a separação por necessidade de técnica, pois em tais casos o evento morte,
} 
sem alterar o nomen iuris do crime a que sucede ou está conexo, forma com este uma unidade complexa. O rigor do Código foi ao ponto de não incluir no setor dos crimes contra a vida, a lesão corporal seguida de morte" (Marques, 1997, p.219).

Nesse mesmo sentido, afirma Aury Lopes Jr:

"A competência do júri é assim muito bem definida no art. $74, \S 1^{\circ}$, de forma taxativa e sem admitir analogias ou interpretação extensiva. Logo, não serão julgados no júri os crimes de latrocínio, extorsão mediante sequestro e estupro com resultado morte, e demais crimes em que se produz o resultado morte, mas que não se inserem nos 'crimes contra a vida'. Essa competência originária não impede que o Tribunal do Júri julgue esses delitos ou qualquer outro (tráfico de drogas, porte ilegal de arma, roubo, latrocínio etc.), desde que seja conexo com um crime doloso contra a vida" (Lopes Jr, 2014, p.1016)

No entanto, o Supremo Tribunal Federal já pacificou a controvérsia do assunto, haja vista a edição do enunciado sumular de $n^{\circ} 603$ acerca da matéria: "A competência para o processamento e julgamento de latrocínio é do juiz singular e não do Tribunal do Júri."

Com relação à possibilidade de ampliação da competência do Tribunal do Júri para o julgamento de outras infrações penais, isto e, a dilatação do rol descrito pelo texto constitucional do art. $5^{\circ}$, inciso XXXVIII, alínea d), posiciona-se José Frederico Marques:

"Em nosso entender, a corrente restritiva é que está com a razão, mesmo porque não se pode ampliar a competência do Júri, contra dispositivos legais, visto tratar-se de um juízo especial” (Marques, 1997, p.222)

No entanto, deve-se registrar outra corrente doutrinária que interpreta o assunto de modo diverso, de cunho majoritário. Nesse sentido, segundo Renato Brasileiro de Lima:

\footnotetext{
"Trata-se de uma competência mínima, que não pode ser afastada nem mesmo por emenda constitucional, na medida em que se trata de clausula pétrea (CF, art. 60, parágrafo $4^{\circ}$, inciso IV), o que, no entanto, não significa que o legislador ordinário não possa ampliar o âmbito de competência do Tribunal do Júri” (Lima, 2015, p.1320).
} 
Outra importante discussão acerca da competência para o julgamento dos crimes dolosos contra a vida envolve a questão do trâmite da $1^{a}$ fase do procedimento em vara especializada, qual seja, de Violência Doméstica e Familiar contra a Mulher.

O precedente relativo ao caso mencionado envolvia a edição de resolução (qual seja, Resolução 18/2006) pelo Tribunal de Justiça de Santa Catarina que, em seu parágrafo único do art. $2^{\circ}$, previa que "na hipótese de crimes dolosos contra a vida, a competência estender-se-á até a fase do art. 412 do Código de Processo Penal" (atual art. 421 CPP). Assim, durante o trâmite da $1^{\text {a }}$ fase do processamento de um crime doloso contra a vida, no qual houvesse a presença de violência doméstica e familiar contra a mulher, até a sentença de pronúncia, a respectiva vara especializada seria competente para tal.

Nestes termos, manifestou-se o Supremo Tribunal Federal no sentido de que tal resolução encontra-se em conformidade com a Lei Maior:

"HABEAS CORPUS. CONSTITUCIONAL E PROCESSUAL PENAL. PACIENTE DENUNCIADO POR SUPOSTO HOMICÍDIO PRATICADO CONTRA SUA ESPOSA. PROCESSO QUE TEVE INÍCIO EM JUIZADO DE VIOLÊNCIA DOMÉSTICA E FAMILIAR CONTRA A MULHER. PREVISÃO DO ART. 14 DA LEI 11.340/2006. INSTRUÇÃO ENCERRADA NOS TERMOS DO ART. 412 DO CPP [ATUAL ART. 421 DO CPP]. REDISTRIBUIÇÃO À VARA DO TRIBUNAL DO JÚRI. INSTALAÇÃO DE VARAS ESPECIALIZADAS POR MEIO DE RESOLUÇÃO DO TRIBUNAL DE JUSTIÇA. CONSTITUCIONALIDADE. AUTORIŻAÇÃO DO ART. 96, I, “A”, DA CONSTITUIÇÃO FEDERAL. DEMAIS QUESTÕES NÃO SUSCITADAS NO STJ. SUPRESSÃO DE INSTÂNCIA. IMPETRAÇÃO PARCIALMENTE CONHECIDA E DENEGADA.

1. A distribuição da ação penal ao Juízo da $3^{\mathrm{a}}$ Vara Criminal e Juizados de Violência Doméstica e Familiar contra a Mulher ocorreu nos termos da legislação vigente à época em que o ato foi praticado. Quando da homologação da prisão em flagrante, encontrava-se em vigor a Lei Maria da Penha (Lei 11.340/2006), que, no ponto, foi regulamentada pela Resolução 18/2006-TJ/SC, não havendo razão para que a ação penal fosse atribuída à $1^{\mathrm{a}}$ Vara Criminal da Capital, tal como antes previsto no art. 107 da Lei Estadual 5.624/1979 (Código de Divisão e Organização Judiciárias do Estado de Santa Catarina). Com o julgamento do recurso em sentido estrito, mantendo a sentença de pronúncia, o processo baixou à origem e foi redistribuído à Vara do Tribunal do Júri da Capital, então recém-implantada pela Resolução 46/2008 -TJ/SC. 
2. Tanto a anexação dos Juizados de Violência Doméstica e Familiar contra a Mulher à $3^{\text {a }}$ Vara Criminal da Capital quanto a instalação da Vara do Tribunal do Júri da Capital, ambas por meio de Resoluções do TJ/SC, se deram em conformidade com a Constituição Federal, que, em seu art. 96, I, "a", autoriza aos Tribunais alterar a competência dos seus respectivos órgãos jurisdicionais e administrativos, desde que observadas as normas de processo e as garantias processuais das partes, como ocorreu no caso. Precedentes.

(...)

4.Habeas corpus conhecido em parte e denegado.”

(STF, $2^{\text {a }}$ Turma, HC 102.150/SC, Rel. Ministro Teori Zavascki, Brasília, 27 mai. 2014) 


\section{CAPÍTULO III- ATRIBUTOS DO CONSELHO DE SENTENÇA}

\subsection{Os jurados no Tribunal do Júri}

Inicialmente, é mister a compreensão acerca da formação do Tribunal do Júri. Sua composição apresenta um juiz togado (figura responsável por presidir os trabalhos), 25 jurados sorteados dentre os alistados (art. 433, CPP), dentre eles os 7 que formarão o Conselho de Sentença em cada julgamento. Muito embora o Ministério Público e o defensor sejam partes obrigatórias nos trabalhos do Tribunal do Júri, formalmente, eles não compõem a referida instituição.

No tocante ao exercício efetivo da função do jurado enquanto competente para o julgamento dos crimes dolosos contra a vida (art. $5^{\circ}$, XXXVIII, alínea “d)" CF), trata-se de serviço público considerado relevante. Nesse sentido, a função de jurado estabelece presunção de idoneidade moral (art. 439 CPP).

Segundo o professor Renato Brasileiro de Lima,

"A doutrina sempre divergiu quanto ao significado da expressão exercício efetivo da função de jurado para que o jurado fizesse jus aos direitos enumerados no art. 439 do CPP. Mirabete compreende por efetivo exercício da função de jurado o comparecimento do jurado ao dia da sessão, ainda que não seja sorteado para compor o conselho de sentença, diante do que preceitua o próprio art. 447 do CPP, que, localizado na Seção IX ("Da composição do Tribunal do Júri e da Formação do Conselho de Sentença") do Capítulo que versa sobre o procedimento do júri, dispõe que o Tribunal do Júri é composto por 1 (um) juiz togado, seu presidente e por 25 (vinte e cinco) jurados que serão sorteados dentre os alistados, 7 (sete) dos quais constituirão o Conselho de Sentença em cada sessão de julgamento. A nosso ver, o exercício efetivo da função de jurado demanda a participação em um julgamento, compondo o conselho de sentença" (Lima, 2015, p.1366)

É interessante notar a democratização do acesso à função de jurado. $\mathrm{O}$ primeiro marco legal de previsão da instituição do Tribunal do Júri no Brasil deu-se por meio da Lei 18 de junho de 1822, conforme fora outrora desenvolvido. $\mathrm{O}$ conteúdo do referido instrumento legal trazia consigo inúmeros requisitos de ordem socioeconômica para se exercer a referida 
atribuição de jurado. Assim, a função pública exigia que o indivíduo fosse do gênero masculino, eleitor (titular de direitos políticos, portanto), de reputação ilibada, inteligente e patriota.

Atualmente, consoante a norma prevista pelo art. 436, $1^{\circ} \mathrm{CPP}$, é inadmissível o impedimento do exercício da função de jurado por motivos discriminatórios, quais sejam, de ordem de raça, etnia, cor, credo, sexo, profissão, classe social ou econômica, origem ou grau de instrução.

Nesse sentido, abaixo, julgado proferido pelo TJRJ, no sentido de observar o conteúdo democrático estabelecido pela norma supracitada:

"APELAÇÃO CRIMINAL. TRIBUNAL DO JURI. CRIMES DOLOSOS CONTRA A VIDA. HOMICÍDIO QUALIFICADO. MOTIVO FÚTIL. NULIDADE POSTERIOR À PRONÚNCIA. JURADOS INAPTOS PARA O JULGAMENTO. INOCORRÊNCIA. MÉRITO.DOSIMETRIA DA PENA INADEQUADA. REFORMA DA SENTENÇA. REDUÇÃO DA PENA-BASE. NECESSIDADE. CIRCUNSTÂNCIAS JUDICIAIS MAJORITARIAMENTE FAVORÁVEIS.

Conselho de Sentença composto por dois jurados analfabetos. Rejeição da alegação de nulidade. Não foi demonstrado nos autos o prejuízo causado ao réu, para ser reconhecida tal nulidade para anular o julgamento pelo Tribunal de Júri. Ainda, o artigo 436, $\S 1^{\circ}$ do Código de Processo Penal, dispõe que: "Nenhum cidadão poderá ser excluído dos trabalhos do júri ou deixar de ser alistado em razão de cor ou etnia, raça, credo, sexo, profissão, classe social ou econômica, origem ou grau de instrução". Assim, inexiste vedação da participação de analfabetos no serviço do Tribunal do Júri, essencialmente composto como retrato da sociedade que representa. Ademais, não haveria como acolher a preliminar porque, tratando-se de nulidade relativa, não foi arguida em momento oportuno, ensejando preclusão.

(...)

PARCIAL PROVIMENTO ao recurso, para reduzir a pena fixada para 13 (treze) anos de reclusão, em regime inicial fechado, mantendo, no mais, a r. sentença vergastada."

(TJRJ, Sétima Câmara Criminal, Apelação Criminal no 0000040-44.2012.8.19.0070, Rel. Desembargador Joaquim Domingos de Almeida Neto, Rio de Janeiro, 13 jan. 2015)

No entanto, há corrente doutrinária que entende de modo diverso ao que fora estabelecido neste julgado acima mencionado, como é o caso do professor Renato Brasileiro de Lima: 
"Apesar de não estar previsto expressamente no texto da lei, a alfabetização também é requisito indispensável para o exercício da função de jurado. Se a própria Constituição Federal assegura o sigilo das votações, é evidente que o jurado precisa ser alfabetizado, sob pena de sequer conseguir ler o conteúdo das cédulas (sim ou não), o que demandaria várias explicações do juiz presidente, dificultando a colheita dos votos e pondo em risco a incomunicabilidade dos jurados (...) É bem verdade que o art. $436, \S 1^{\circ} \mathrm{CPP}$ prevê que nenhum cidadão poderá ser excluído dos trabalhos do júri ou deixar de ser alistado em razão de seu grau de instrução. Porém, daí não se pode extrair a conclusão de que o jurado não precisa ser alfabetizado. Na verdade, quando o dispositivo faz menção ao grau de instrução do jurado, refere-se à irrelevância de o jurado ter o ensino fundamental, médio ou superior completo. Para que ele possa ser jurado, basta que seja alfabetizado, mesmo que não tenha completado o ensino fundamental" (Lima, 2015, p.1363).

Além disso, importante consideração acerca dos jurados é que, embora seja um serviço obrigatório (art. 436, caput CPP), existem hipóteses que ensejam a isenção de tal atribuição, conforme se verifica na norma descrita pelo art. 437 CPP que, em seu inciso $\mathrm{X}$, prevê elemento normativo, isto é, que depende de juízo valorativo do intérprete.

Neste diapasão, afirma o professor Renato Brasileiro de Lima:

"Nem todos os cidadãos maiores de 18 (dezoito) anos de notória idoneidade podem ser jurados. De acordo com o art. 437 do CPP, há diversas pessoas que estão isentas do serviço do júri. Especial atenção deve ser dispensada ao art. 437, X, do CPP, que passou a prever que qualquer pessoa que o requerer, demonstrando justo impedimento, poderá ser isenta do Júri. Trata-se de cláusula aberta, que deixa a critério do Juiz, inspirado no bom senso, decidir se é caso ou não de dispensa, à vista do caso concreto. Deve ser utilizada quando restar demonstrado que o exercício da função de jurado é incômoda ao referido cidadão (v.g., mulher no período de amamentação) ou nociva ao desenvolvimento de suas atividades profissionais" (Lima, 2015, p.1364)

Somado a isso, deve-se observância ao dispositivo do art. $5^{\circ}$, VIII CF, em relação à possibilidade de escusa de consciência. Assim, se o indivíduo, por questões de crença religiosa ou de convicção filosófica ou política se recusar a cumprir o serviço obrigatório do júri, trata-se de aplicação da norma disposta pelo art. $438 \mathrm{CPP}$.

Nesse sentido, trata-se de hipótese de aplicação de serviço alternativo, sob pena de suspensão dos direitos políticos. O art. $438 \mathrm{CPP}$, em seu parágrafo $1^{\circ}$, traz a definição de serviço alternativo, que será designado de 
acordo com os princípios da proporcionalidade e da razoabilidade (parágrafo $2^{\circ}$ do mesmo dispositivo).

\subsection{O quantum de julgadores no Conselho de Sentença}

Segundo o disposto pelo art. 463, caput CPP, uma vez constatada a presença de quinze jurados, o juiz presidente declarará instalados os trabalhos. Nesta oportunidade, é realizado o sorteio para composição do Conselho de Sentença (art. 467 CPP), que deve ser formado pela quantidade de sete julgadores.

Assim, de acordo com o disposto pelos artss. 473, 474, 476 e 477, todos do CPP, após a oitiva da vítima (se houver), testemunhas, peritos, interrogatório (caso o réu exerça seu direito à autodefesa), debates entre acusação e defesa, eventuais réplica e tréplica, o corpo de jurados deverá se reunir na chamada sala secreta, em observância ao princípio constitucional do sigilo das votações (art. 5, XXXVIII, alínea "b)" CF), para proferir seus votos diante dos quesitos formulados pelo juiz presidente.

Desse modo, consoante a inteligência do art. 483 CPP e seus incisos, serão propostos ao Conselho de Sentença, nesta ordem, os seguintes quesitos: materialidade do fato, autoria ou participação, se o acusado deve ser absolvido, se existe causa de diminuição de pena alegada pela defesa, se há circunstância qualificadora ou causa de aumento de pena reconhecidas na pronúncia ou em decisões posteriores que julgaram admissível a acusação.

Segundo a norma prevista pelo art. 489 CPP, as decisões do Tribunal do Júri serão realizadas levando em conta a maioria simples de votos, considerando o total de 7 (sete) jurados como componentes do Conselho de Sentença. Em outras palavras, 4 (quatro) votos contra 3 (três) são o bastante para ser vislumbrada a maioria que possui o condão de proferir o veredicto, seja no sentido de absolvição, seja no sentido de condenação. 
Em sede de Direito Comparado, percebem-se composições diversas na quantidade de jurados membros do Conselho de Sentença do Tribunal do Júri, se comparadas ao modelo do Brasil. Além disso, observa-se que o sistema do cômputo de votos pátrio apresenta diferenças notórias em face de países como Inglaterra, Estados Unidos, Espanha e Portugal.

No caso da Inglaterra, o Tribunal do Júri é composto por 12 (doze) indivíduos. Para que o réu seja condenado, deve haver a constatação de pelo menos 10 (dez) votos no sentido de condenação. Trata-se, portanto, do sistema da maioria qualificada no cômputo dos votos. Caso tal quórum não seja vislumbrado, o réu deverá ser submetido a um novo julgamento, composto por novos jurados. Na hipótese de este segundo júri ocorrer e, não sendo observada a referida maioria qualificada, o réu será absolvido, por ser considerado inocente.

Em relação aos Estados Unidos, deve-se levar em conta que cada Estado membro da Federação possui suas próprias normas acerca da formação júri e da quantidade de jurados presentes no Conselho de Sentença, bem como no tocante ao quantum de votos capaz de ensejar a condenação do acusado. Desse modo, constata-se que 7 (sete) de seus Estados membros observam a composição de 12 (doze) julgadores, cuja apuração de votos deve apresentar resultado unânime, para fins de condenação, seja em causas cíveis, seja em causas criminais. Em outros Estados membros, de outra sorte, o critério para condenação exige uma maioria de dois terços dos votos, isto é, trata-se de um quórum qualificado.

Na Espanha, o Tribunal do Júri é formado por 9 (nove) jurados, além do magistrado, responsável por presidir os trabalhos. A condenação do réu efetiva-se com 7 (sete) votos nesse sentido. Um recurso bastante relevante de que dispõe o júri espanhol é a possibilidade de entrevistar os candidatos à função de jurado, com intuito de perceber suas convicções sociais, 
impressões políticas e eventuais preconceitos que, por vezes, podem ser, de forma infeliz, responsáveis pelo modo com que o jurado proferirá seu voto.

Em Portugal, consoante as ensinam as palavras de Germano Marques da Silva, processualista português, o Tribunal do Júri é formado da seguinte forma:

"O Tribunal do Júri português é composto pelos três juízes que constituem o tribunal coletivo e por quatro jurados efetivos e quatro suplentes, sendo presidido pelo presidente do tribunal coletivo e intervindo os jurados suplentes quando, durante o julgamento ou antes do seu início, algum dos efetivos se impossibilitar" (Silva, 2000, p.211).

Curiosamente, em regra, o júri português possui caráter facultativo, isto é, depende de provocação, requerimento. Assim dispõe a redação do art. $13^{\circ}$ do Código de Processo Penal lusitano:

"Compete ao Tribunal do Júri julgar os processos que, tendo a intervenção do júri sido requerida pelo Ministério Público, pelo assistente ou pelo arguido, respeitarem a crimes previstos no título II e no capítulo I do título V do livro II do Código Penal."

No tocante ao quórum de votação, o júri português assemelha-se ao modelo brasileiro, haja vista que, para ocorrência da condenação, devem ser contabilizados os votos por maioria simples, isto é, na quantidade de 4 (quatro) votos, segundo a dicção do art. $365^{\circ}$, item 5 do Código de Processo Penal português, dispositivo este que trata da deliberação e votação no Tribunal do Júri.

Diante disso, sobrevém a seguinte indagação: seria 7 (sete) o número adequado de julgadores presentes no Conselho de Sentença, considerando que a decisão é tomada por maioria simples, modelo esse adotado pelo Brasil? Em um cômputo de 4 votos contra 3, é possível vislumbrar uma margem de segurança na tomada de decisão? Seria razoável a possibilidade de condenação/absolvição de um indivíduo acusado de um homicídio qualificado (crime hediondo, segundo o art. $1^{\circ}$, I da lei 8.072/90), por 
exemplo, pela contagem de apenas 4 votos, ao passo que 3 deles foram em sentido diverso?

Nesse diapasão, preleciona Aury Lopes Jr acerca do tema:

"Quando os jurados decidem pela condenação do réu por 4x3, está evidenciada a dúvida, em sentido processual. Significa dizer que existe apenas $57,14 \%$ de consenso, de convencimento. Questiona-se: alguém admite ir para a cadeia com 57,14\%? Elementar que não. A sentença condenatória exige prova robusta, alto grau de probabilidade (de convencimento), algo incompatível com um julgamento por $4 \times 3$, mas isso ocorre diuturnamente no Tribunal do Júri (...) O aumento do número de jurados é imprescindível, não apenas para dar uma maior representatividade do corpo social no conselho de sentença, mas, principalmente, para a máxima eficácia do direito constitucional de defesa (...) Estamos plenamente de acordo: o número par de jurados (8) resolveria esse problema, pois a condenação somente ocorreria com uma diferença de, no mínimo, dois votos. O aumento do número de jurados é imprescindível, não apenas para dar uma maior representatividade do corpo social no conselho de sentença, mas, principalmente, para dar a máxima eficácia do direito constitucional de defesa" (Lopes Jr, 2014, p.1079/1080).

Consoante o entendimento de Moreira de Oliveira, que acompanha o mesmo posicionamento de Aury Lopes Jr, o quantum de jurados, membros do Conselho de Sentença, deveria ser revisitado e, portanto, alterado nos seguintes termos:

"Sugeriu o ilustre professor que o número de jurados passasse para 8, ou seja, um número par de integrante que impediria soluções duvidosas como as que ocorrem atualmente, pois, 'em caso de empate, teríamos a configuração da dúvida favorecedora da absolvição, pois argumentos acusatórios e defensivos não lograram obter maioria', utilizando-se aqui o art. $615, \S 1^{\circ}$, do CPP por analogia. Com essa simples modificação sugerida pelo autor, havendo oito jurados, alguém somente seria condenado se houvesse no mínimo dois votos de diferença, isto é, cinco contra três. Com isso se conferiria maior certeza e seriedade a uma solução condenatória, pois se reduziria a possibilidade de erro cometido por um só jurado" (Lopes Jr, 2014, p.1080).

No entender do professor César Faria, sendo ele defensor que o quórum necessário à condenação fosse estabelecido com o cômputo de 5 (cinco) votos,

\footnotetext{
"Ressalte-se, por oportuno, que o número ímpar de jurados, por si só, não é antidemocrático, desde quando se exija uma maioria qualificada para condenação. Nesta senda, poder-se-ia manter o número 7 de jurados, desde que se exigisse para condenação, pelo menos, 5x2(...) Se o Brasil constitui-se em um Estado Democrático de Direito, como proclama o art. $1^{\circ}$ da Constituição da República, não pode continuar a admitir condenação na dúvida, como, desgraçadamente, ainda ocorre no Tribunal
} 
do Júri, pois a dúvida é a certeza dos loucos e os loucos não julgam, nem podem ser julgados" (Faria, 2016, s.p).

Portanto, observa-se que o quórum de 7 (sete) jurados componentes do Conselho de Sentença, somado ao fato de que as decisões são tomadas por maioria simples são aspectos que ensejam polêmicas e críticas no âmbito do Tribunal do Júri. Indubitavelmente, a análise comparativa de ordenamentos jurídicos alienígenas é um fator que gera inquietude naqueles que rechaçam as referidas características do modelo brasileiro. Isso porque, consoante fora outrora desenvolvido, há países que exigem quórum qualificado para que a condenação seja proferida, ou até mesmo a unanimidade dos votos, além do fato de que o corpo de jurados apresenta, em muitos casos, maior quantidade, o que aumenta, em termos probabilísticos, de forma matemática, a margem de certeza da decisão.

\subsection{A incomunicabilidade dos jurados}

Ao longo da história do Tribunal do Júri no Brasil, a deliberação entre o corpo de jurados era um atributo inerente ao referido instituto. Consoante a dicção do art. 248 do Código de Processo Criminal de 1832,

"Finda a ratificação do processo, ou formada a culpa, o Presidente fará sahir da sala as pessoas admitidas, e depois do debate, que se suscitar entre os jurados, porá a votos a questão seguinte: Procede a acusação contra alguém? (...)"

No entanto, a partir da Era Vargas, com a edição do Código de Processo Penal, a comunicação entre os jurados acerca do processo em julgamento foi proibida, motivo pelo qual a incomunicabilidade entre os membros Conselho de Sentença passou a ser norma. O Decreto Lei 167/38 iniciou o movimento em que se observa na regra de incomunicabilidade do atual Código de Processo Penal (1941). De acordo com a disposição do art. 75 do referido decreto lei, 
"Fechadas as portas, o conselho, sob a presidência do juiz, assistido do escrivão, que servirá de secretário, do promotor e do advogado, que se conservarão nos seus lugares, sem intervir nas discussões e votações, e de dois oficiais de justiça, passará a votar os quesitos que lhe forem propostos observada completa incomunicabilidade dos jurados."

Em 2008, por meio da Lei 11.689, a instituição do Tribunal do Júri sofreu diversas alterações, como por exemplo o aumento do quantum de jurados alistados de acordo com o tamanho da cidade, a redução da idade mínima para o exercício da atividade de jurado (de vinte e um anos, passou a ser dezoito), dentre outras mudanças. No entanto, permaneceu imutável aos olhos do legislador o dispositivo do art. $466, \S \S 1^{\circ}$ e $2^{\circ}$ do CPP.

Nestes termos, consoante a inteligência do art. $466, \S \S 1^{\circ}$ e $2^{\circ}$ do CPP, os julgadores, componentes do Conselho de Sentença, não podem proferir suas impressões ou manifestações de opinião acerca do processo em análise. Assim, haja vista o fato de a lei processual penal vedar a possibilidade de interação entre os jurados para fins de tomada de decisão, afirma-se que o sistema brasileiro do Tribunal do Júri adotou a incomunicabilidade dos jurados.

Em âmbito de Direito Comparado, o júri da Inglaterra, dos Estados Unidos e de Portugal permitem a comunicabilidade entre os jurados. Uma produção cinematográfica americana que ilustra de forma palpável a dinâmica do júri anglo saxão, especialmente no tocante à deliberação entre os julgadores, é o filme "Twelve Angry Men" (no Brasil, traduzido como "Doze Homens e uma Sentença". Na referida obra, para que o acusado fosse condenado, seriam necessários 12 (doze) votos nesse sentido, isto é, seria imprescindível a unanimidade. No entanto, apenas 1 (um) dos jurados discorda do veredicto de condenação, motivo pelo qual promoveu o debate e a argumentação com os demais componentes do júri. Sobre a importância da comunicação entre os jurados e o filme "Doze Homens e uma Sentença", reflete Paulo Rangel: 
"Para tanto, o filme DOZE HOMENS E UMA SENTENÇA (1957) - com Henry Fonda -, deixa clara a importância do exercício da linguagem no Tribunal do Júri onde o fato óbvio, claro para alguns jurados, até porque é fácil condenar o outro, em verdade necessita de uma discussão maior, de uma pesquisa diferenciada, de ouvir com ouvidos de quem quer conhecer e enxergar com olhos de quem quer ver as provas dos autos, até chegar à comprovação da inocência do acusado. A linguagem, portanto, é exercício de democracia processual onde o outro será julgado, através de seus pares, com a ética devida e necessária. $\mathrm{O}$ fato de um jurado poder influenciar outro, durante a discussão da causa, não pode, por si só, obstar o exercício da linguagem. Tal influência, se houver, é fruto do sistema democrático de que o poder emana do povo e em seu nome é exercido, pois a eleição comum de candidatos a cargo público também está sujeita a tal influência e nem por isso perde seu caráter de representatividade popular. No júri, quanto maior for a discussão da causa, mais representativa será a decisão dos jurados" (Rangel, 2018, p.91).

A respeito da possibilidade de deliberação entre o corpo de jurados em Portugal, preleciona Lenio Luiz Streck:

"Na sala secreta, o juiz-presidente fará a leitura dos quesitos, explicando-os, sem fazer, no entanto, qualquer resumo dos debates ou sobre as provas produzidas em plenário. Os jurados poderão pedir esclarecimentos ao juiz-presidente. Os votos serão proferidos oralmente, em ordem crescente por idade, votando primeiro os jurados (leigos), para depois votarem os juízes togados, votando por último o presidente. O júri poderá dar como provado qualquer fato, mesmo que não esteja compreendido nos quesitos, desde que seja para beneficiar o acusado. Importante registrar que a pena é fixada pelo tribunal coletivo. As decisões são tomadas por maioria simples. Cada juiz e cada jurado deve enunciar as razões da sua opinião, indicando, sempre que possível, os meios de prova que serviram para formar sua convicção. Não é permitida abstenção. Nem os juízes que constituem o Tribunal coletivo nem qualquer dos jurados poderão revelar o que se tenha passado durante a deliberação e que se relacione com a causa, nem exprimir a sua opinião sobre o veredicto do Júri depois de proferido" (Streck, 2001, p.83).

A questão da incomunicabilidade dos jurados suscita opiniões divergentes. Há doutrinadores que entendem ser uma característica positiva no que diz respeito ao processo de tomada de decisão. Nesse sentido, no entender de Firmino Whitaker, defensor da incomunicabilidade dos jurados: “A lei, exigindo a incomunicabilidade, pretendeu garantir a independência dos jurados e a verdade das decisões. Só a própria convicção os deve guiar no julgamento" (Whitaker, 1930, p.83).

Paulo Rangel, em opinião contrária, no sentido de defender a deliberação entre os jurados, propõe que a incomunicabilidade seja objeto de reforma legislativa: 
"Tem-se por objetivo, agora, propor uma reforma no júri, em especial na parte referente à incomunicabilidade, deixando uma contribuição, não obstante se entenda que tal reforma não pode ser apenas no júri, mas sim em todo o Código" (Rangel, 2018, p.96).

De acordo com Eric Hadmann Jasper, também contrário à questão da incomunicabilidade, a deliberação é um aspecto que pode resultar na melhoria da qualidade dos votos dos jurados:

\begin{abstract}
"Resta, portanto, demonstrar como a deliberação pode melhorar a competência dos jurados. Existem várias formas de se responder a essa questão. A primeira é baseada na confiança de que uma pessoa melhor preparada para a decisão específica do grupo pode auxiliar as pessoas menos preparadas. É plausível pensar que uma parte considerável dos problemas de preparo de jurados seja devido à ausência de familiaridade com o assunto em questão. Algo que uma pessoa bem preparada e autorizada a expor razões poderia, ao menos em tese, resolver. Essa ideia também admite a possibilidade de que não apenas pessoas melhor preparadas, mas simplesmente pessoas detentoras de diferentes informações ou opiniões possam apresentar publicamente suas opiniões e, necessariamente, as razões que as fundamentam. Com isso, é plausível que os demais membros do júri ao menos utilizem as novas informações ou opiniões para modificar sua posição anterior ou fortalece-la por meio de novas razões. Não há, ao menos em princípio, risco de dano ao processo decisório de cada jurado, muito pelo contrário. Uma outra possiblidade menos "otimista" é fundamentada no pressuposto de que os problemas da tentação de jurados votarem preferências e não julgamentos de valor, poderia ser resolvida pela "publicidade" das discussões. Também é plausível pensar que é menor a probabilidade das pessoas exporem preconceitos durante uma discussão, simplesmente porque o grupo que delibera não aceitaria essa modalidade de argumentação como válida" (Jasper, 2008, p.463).
\end{abstract}

Do ponto de vista filosófico, há pensadores que rechaçam a questão da deliberação como fator positivo na tomada de decisões em conjunto. Em outras palavras, é dizer que encontram na incomunicabilidade um atributo favorável na qualidade do processo de tomada de decisões. Tal posicionamento filosófico revela-se aplicável do ponto de vista da análise da incomunicabilidade no Tribunal do Júri. Isso porque os filósofos contratualistas, como é o exemplo de Jacques Rousseau, possuem como objeto principal a autopreservação e o bem estar geral- assim, evidentemente, são aspectos que abrangem o instituto do júri, pois é o órgão competente para julgamento dos crimes que mais escandalizam e impressionam, em tese, os indivíduos de uma sociedade. Nesse sentido, Rousseau manifesta suas lições em sua obra $O$ contrato social: 
"Se, quando o povo, suficientemente informado, delibera, não tivessem os cidadãos nenhuma comunicação entre si, sempre resultaria a vontade geral do grande número de pequenas diferenças, e a deliberação seria sempre boa" (Rousseau, 1762, p.41).

Diante de tais considerações, observa-se que a incomunicabilidade entre o corpo de jurados é um aspecto que suscita polêmica e divergências no instituto do Tribunal do Júri. Há quem entenda que a incomunicabilidade entre os membros do Conselho de Sentença é uma característica antidemocrática, como é o exemplo de Paulo Rangel, que assim afirmou: "Fruto do sistema político autoritário e da sociedade agrária da época, a incomunicabilidade impede a discussão do caso, em si, colocando fora do discurso a liberdade do outro, como outro excluído socialmente" (Rangel, 2018, p.196). 


\title{
CAPÍTULO IV- A (IM)PARCIALIDADE NA TOMADA DE DECISÃO PELOS JURADOS
}

\subsection{A hipótese legal do desaforamento}

Assim determina o art. 427, caput CPP, cuja redação fora dada pela Lei $\mathrm{n}^{\circ} 11.689 / 08$ :

\begin{abstract}
"Se o interesse da ordem pública o reclamar ou houver dúvida sobre a imparcialidade do júri ou a segurança pessoal do acusado, o Tribunal, a requerimento do Ministério Público, do assistente, do querelante ou do acusado ou mediante representação do juiz competente, poderá determinar o desaforamento do julgamento para outra comarca da mesma região, onde não existam aqueles motivos, preferindo-se as mais próximas."
\end{abstract}

Uma primeira premissa que merece ser destacada é o fato de que, diante da leitura do dispositivo supracitado, pode-se afirmar que o próprio legislador reconhece a hipótese de a imparcialidade tornar-se prejudicada, em sede de julgamento pelo Conselho de Sentença, no momento da Sessão Plenária do Tribunal do Júri.

Para fins do presente trabalho, no entanto, o desaforamento será analisado tão somente do ponto de vista da referida imparcialidade, sem prejuízo da existência de motivos de interesse de ordem pública, por questões de segurança pessoal do acusado ou até mesmo em razão de comprovado excesso de serviço (art. $428 \mathrm{CPP}$ ). Com relação ao desaforamento por quebra da imparcialidade dos jurados, manifesta-se Renato Brasileiro de Lima:

\footnotetext{
"Estará presente quando a infração penal, apaixonando a opinião pública, gerar no meio social animosidade, antipatia e ódio ao acusado. Bom exemplo dessa hipótese é quando o pronunciado ou sua família exercem grande influência econômica ou política, ou ambas, e essa influência seja capaz de abalar a imparcialidade do júri em seu benefício" (Lima, 2015, p.1356).
}

Nesse sentido, com intuito de prevenir a ocorrência de julgamentos despidos de imparcialidade dos julgadores, o requerimento da parte interessada no pedido de desaforamento é um requisito conferido pela própria 
lei. Contudo, é mister a observância do Enunciado da Súmula 712 do STF, que assim o dispõe: "É nula a decisão que determina o desaforamento de processo da competência do júri sem audiência da defesa."

Portanto, o pedido de desaforamento, caso seja realizado pelo Ministério Público ou assistente de acusação, por exemplo, não poderá ser deferido sem prévia manifestação da defesa, sob pena evidente de violação do princípio do contraditório e ampla defesa.

Com relação ao momento processual adequado para que seja feito o pedido de desaforamento, preleciona Renato Brasileiro de Lima:

\begin{abstract}
"Só há falar em desaforamento após a decisão de pronúncia, como deixa entrever o art. $427, \S 4^{\circ}$, do CPP. Portanto, não é possível o desaforamento se ainda está pendente o recurso da defesa contra pronúncia, ou seja, só é possível após a preclusão da decisão de pronúncia do réu, mesmo porque, até então, não há como se cogitar de julgamento pelo Tribunal do Júri, diante da possibilidade de não ser o acusado pronunciado (desclassificação da imputação, impronúncia ou absolvição sumária) ou de ser a pronúncia reformada em sede recursal. Mas e depois do julgamento pelo Júri? Ainda é possível o desaforamento? Somente se admite o desaforamento após julgamento pelos jurados se somadas duas condições (CPP, art. $427, \S^{\circ}$ ): se houver nulidade da decisão e o fato tiver ocorrido durante ou após a realização do julgamento. Assim, se no curso do julgamento em plenário se verifica que há risco à segurança pessoal do acusado e caso este julgamento venha a ser anulado por qualquer causa, poderá ser formulado novo pedido de arquivamento. A restrição neste ponto tem razão de ser: caso fosse admitido o desaforamento após o julgamento, o instituto poderia ser utilizado para buscar censurar a decisão anterior dos jurados, em violação ao princípio da soberania dos veredictos. Justamente por isto, o simples fato de ter ocorrido fato novo que justifique o desaforamento durante ou após a sessão de julgamento não é suficiente para o pleito de desaforamento posterior" (Lima, 2015, p.1355).
\end{abstract}

Segundo julgados da Corte Constitucional, não é imprescindível a prova da certeza de parcialidade dos jurados. Em outras palavras, basta a existência de fundada dúvida da quebra de imparcialidade para que o desaforamento resulte necessário. Nesse sentido, ementa de julgado da referida Corte:

"Habeas corpus. Desaforamento. Dúvida fundada sobre a parcialidade dos jurados. Manifestação favorável de ambas as partes e do Juízo local pelo acolhimento da proposta, com indicação de fatos concretos indicativos da parcialidade dos jurados. 
Ordem concedida. 1. Segundo a jurisprudência do Supremo Tribunal, a definição dos fatos indicativos da necessidade de deslocamento para a realização do júri desaforamento - dá-se segundo a apuração feita pelos que vivem no local. Não se faz mister a certeza da parcialidade que pode submeter os jurados, mas tão somente fundada dúvida quanto a tal ocorrência. 2. A circunstância de as partes e o Juízo local se manifestarem favoráveis ao desaforamento, apontando-se fato "notório" na comunidade local apto a configurar dúvida fundada sobre a parcialidade dos jurados, justifica o desaforamento do processo (Código de Processo Penal, art. 424). 3. Ordem concedida para determinar o desaforamento para outra Comarca da mesma região onde não subsistam os motivos pertinentes (CPP, art. 429), adotando-se, no caso, a mesma solução dada para casos anteriores relativos ao paciente, qual seja, o desaforamento para o Tribunal do Júri da Comarca de Jundiaí/SP.”

(STF, $1^{\text {a }}$ Turma, HC n ${ }^{\circ}$ 109.023/ SP, Rel. Ministro Dias Toffoli, Brasília, 13 dez. 2011)

Em âmbito doutrinário, Eugênio Pacelli observa o tema com parcimônia:

\begin{abstract}
"Todo cuidado será pouco na aplicação dessa norma. O desaforamento sempre causa tumulto no procedimento, sobretudo em relação à inquirição de testemunhas, cujo depoimento, via de regra, é de fundamental importância na solução da causa. Seria ponderável privilegiar-se a celeridade no julgamento em detrimento da instrução? A nosso aviso, nem sempre. Ou, mais que isso. Pensamos que a aplicação do aludido dispositivo deverá ser a exceção e não a regra, sempre com os olhos postos no eventual risco em relação à instrução do processo, que ficará comprometida com o desaforamento" (Pacelli, 2019, p.762).
\end{abstract}

\title{
Em suas lições críticas, Aury Lopes Jr ressalta relevantes observações
}

com relação à interferência midiática como causa para o desaforamento, por macular a imparcialidade dos jurados:

"É uma causa importante, mas dificílima de ser comprovada e, portanto, admitida. Se a suspeição por quebra da imparcialidade de um juiz de direito ou federal, julgador perfeitamente individualizado, portanto, é rarissimamente reconhecida pelos tribunais (pelos mais diversos motivos, mas principalmente pelo sentido corporativo e protecionismo), imagine-se uma alegação genérica de quebra de imparcialidade de um grupo difuso de jurados. Não significa que o problema não exista, todo o oposto, senão que é de difícil comprovação. Em geral, tal situação decorre do mimetismo midiático, ou seja, o estado de alucinação coletiva (e contaminação psíquica, portanto) em decorrência do excesso de visibilidade e exploração dos meios de comunicação. $\mathrm{O}$ bizarro espetáculo midiático e a publicidade abusiva em torno de casos graves ou que envolva pessoas influentes ou personalidades públicas fazem com que exista fundado receio de que o eventual conselho de sentença formado não tenha condições de julgar o caso penal com suficiente tranquilidade, independência e estranhamento (ou alheamento, desde uma perspectiva de terzietà). Diante disso, proporcional à cautela que devem os tribunais ter ao julgar tal pedido, para evitar uma molesta banalização da medida, está a 
necessidade de ter sensibilidade e coragem para decidir pelo desaforamento quando houver uma dúvida razoável acerca da alegada imparcialidade. Também deve se considerar nessa rubrica o sentimento e prejulgamento gerado não pelo crime em si, mas pela pessoa sujeita ao julgamento, ou seja, como adverte ESPÍNOLA FILHO, há que se distinguir o sentimento de repulsa que em geral acompanha o crime, da animosidade existente contra a pessoa do réu (autorizadora do desaforamento)" (Lopes Jr, 2014, p.1045/1046).

\subsection{A ausência de motivação na tomada de decisão}

Inicialmente, merece destaque o fato de que, no tocante aos sistemas de avaliação da prova, existem 3 (três) principais modelos, consoante destaca a doutrina processualista: o sistema da prova tarifada, o sistema da persuasão racional do juiz (livre convencimento motivado) ou o sistema da íntima convicção.

O sistema da prova tarifada, também conhecido como sistema da certeza moral do legislador ou da prova legal, é uma característica presente no sistema inquisitivo, antidemocrático, sendo este último responsável por reunir em uma só pessoa (juiz inquisidor) as funções de acusar, defender e julgar, o qual fora adotado pelo Direito canônico a partir do século XIII, cuja propagação alcançou todo o continente europeu. No âmbito do sistema da prova tarifada, assim, observa-se a existência de uma ponderação, em abstrato, feita pelo legislador, acerca do valor de cada prova (algumas, portanto, possuíam maior valor em detrimento de outras). A confissão, nesta perspectiva, era a chamada "rainha das provas", haja vista que, uma vez concretizada, nenhuma outra prova era capaz de afastá-la.

De outra sorte, no sistema da persuasão racional do juiz (livre convencimento motivado), não há falar em ponderação do valor de uma prova em detrimento de outra, feita de modo a priori pelo legislador. Todos os conteúdos probatórios, destarte, possuem o mesmo valor do ponto de vista legal, cabendo à figura do magistrado, então, a valoração das provas em cada caso concreto, mediante decisão fundamentada. Trata-se do sistema adotado como regra geral pelo ordenamento jurídico brasileiro, de acordo com a 
interpretação do dispositivo do art. 93, IX da CF. Sobre tal sistema, assevera Gomes Filho:

“A liberdade na apreciação das provas não se confunde com uma autorização para que o juiz adote decisões arbitrárias, mas apenas lhe confere a possibilidade de estabelecer a verdade judicial com base em dados e critérios objetivos e de uma forma que seja controlável" (Badaró et al., 2008, p.249)

Com relação ao sistema da íntima convicção, não há falar em fundamentação do magistrado ao proferir sua decisão. É evidente que tal circunstância apresenta um impasse no controle e sindicância do exercício da função jurisdicional, já que as razões de fato e de direito da decisão não foram exteriorizadas. No Brasil, o sistema da íntima convicção fora adotado em sede das decisões proferidas pelo Conselho de Sentença no Tribunal do Júri. Trata-se, portanto, de uma exceção à regra do sistema do livre convencimento motivado. Nesse sentido, segundo as lições de Renato Brasileiro de Lima:

\begin{abstract}
"O sistema da íntima convicção não foi adotado pelo ordenamento pátrio, pelo menos em regra. De fato, segundo o art. 93, inciso IX, da Constituição Federal, todos os julgamentos dos órgãos do poder Judiciário serão públicos e, fundamentadas todas as decisões, sob pena de nulidade. A despeito da regra constante da Constituição Federal, não se pode negar que referido sistema tenha sido adotado em relação às decisões dos jurados no tribunal do júri, as quais não precisam ser motivadas. Isso porque, de acordo com o art $5^{\circ}$, inciso XXXVIII, da Carta Magna, tem-se como uma das garantias do júri o sigilo das votações. Ou seja, fosse o jurado obrigado a fundamentar sua decisão, seria possível identificar-se o sentido de seu voto. Daí a desnecessidade de fundamentação do voto do jurado, limitando-se o mesmo a um singelo "sim" ou "não" para cada quesito que lhe for formulado, nos exatos termos do art. 486, caput, do CPP" (Lima, 2015, p.603).
\end{abstract}

Nesse sentido, o sistema da íntima convicção na tomada de decisão pelo Conselho de Sentença é, indubitavelmente, um aspecto polêmico em relação ao Tribunal do Júri, dado que a inexistência de fundamentação dos votos impede o controle dos motivos que ensejaram a votação em um sentido ou em outro, eventualmente abusivos e contrários à lógica democrática. Assim, se o jurado, por exemplo, proferiu seu voto no sentido de "não absolver o acusado" (terceiro quesito, de acordo com a ordem estabelecida pelo art. 483, III CPP) por razões íntimas, ligadas a preconceitos pessoais em razão à pessoa do acusado, por discriminação de cor, orientação sexual, classe social 
ou religião, o controle jurisdicional de tal voto torna-se exíguo, haja vista a ausência de motivação na tomada de decisão.

Assim, muitas vezes, as decisões do Tribunal do Júri, uma vez envoltas pelo manto da íntima convicção, podem ser proferidas tendo como base o retrocesso ao Direito Penal do autor, e não o Direito Penal do fato. Tal possibilidade ocorre em razão da ausência de motivação, o que obsta um controle efetivo e razoável das decisões proferidas pelo Conselho de Sentença. Nesse sentido, Lenio Luiz Streck manifesta suas considerações:

\begin{abstract}
"Criou-se, então, no âmbito da dogmática jurídica, a distinção informal entre direito penal do fato e direito penal do autor. Dessa forma, acusa-se, defende-se e julga-se o indivíduo não pelo fato criminoso que cometeu, mas pelo que representa, de forma efetiva, na tessitura da sociedade na qual está inserido. É o papel social do acusado que definirá a maneira como será tratado/julgado. Registre-se que essa tese- que é antiga- surgiu como alternativa entre a teoria realística (tradicional e dominante) e a teoria sintomática. Infiltrou-se no pensamento jurídico com o advento do nacionalsocialismo alemão, chamada então de teoria voluntarista, ou Direito Penal da vontade (Willensstrafrecht), segundo a qual, o crime seria, antes de mais nada, a "violação do dever de fidelidade para com o Estado. Foi estruturada pelo chamado grupo de Kiel, liderado por Shaffstein e Dahm, penalistas do fatídico regime nazista (...) Não é difícil perceber/ constar que nos julgamentos do Tribunal do Júri prevalecem as teses do Direito Penal do autor. Esse tipo de procedimento é exercitado exatamente porque o Direito Penal está inserido em uma sociedade desigual, em que, se o indivíduo tiver bons antecedentes, for um bom pai de família, trabalhador, etc., enfim, se enquadrar segundo os padrões da normalidade estabelecidos pela sociedade dominante, terá maiores possibilidades de ser absolvido do que alguém classificado/ rotulado como desviante. Este perfil das "relações adequadas, normais, entre homens e mulheres não é nunca posto em questão nas discussões jurídicas: o que se tenta fazer é enquadrar homens e mulheres concretos dentro das regras idealizadas e comprovar a sua maior ou menor adesão a elas. Do sucesso dessa operação é que vai depender, então, a condenação ou absolvição dos acusados ante o júri, onde o que se pune é a conduta social do acusado e da vítima, e não do crime cometido" (Streck, 2001, p.117/118).
\end{abstract}

Acerca do sistema da íntima convicção no Tribunal do Júri, continua

Lenio Luiz Streck: "Nesse sentido, e correndo o risco de pesadas críticas, chamo a atenção da
comunidade jurídica acerca daquilo que pode ser considerado o "calcanhar de
Aquiles" do Tribunal do Júri, no confronto com o garantismo jurídico. Refiro-me ao
fato de o jurado decidir por íntima convicção, sem a necessidade de justificar seu
voto. O modelo de Estado Democrático de Direito, garantista e secularizado,
dificilmente poderá continuar a conviver com julgamentos nos quais não haja a
devida justificação/ fundamentação. Entretanto, trata-se de um problema de difícil
solução, uma vez que a Constituição estabelece a garantia do "sigilo das votações", 
o que implica a impossibilidade imediata de qualquer tentativa de introduzir outros modelos de julgamento popular, como, por exemplo, o escabinato francês ou o português ou até mesmo uma adaptação das fórmulas tradicionais do júri americano ou inglês, onde os jurados discutem entre si, buscando um consenso (...) A possibilidade de alteração do júri depende, à evidência, de emenda à Constituição, em face do obstáculo representado pela garantia do sigilo das votações. Não creio, por outro lado, que uma emenda constitucional nesse sentido tenha o condão de violar as cláusulas pétreas. Com efeito, a Constituição Federal estabelece a vedação de emendas tendentes a abolir garantias. Ora, o que não pode ser extinto é o Tribunal do Júri e nem a soberania de seus veredictos. Observe-se que, na França e em Portugal, nada do que foi discutido na sala secreta pode ser revelado. Há a garantia do sigilo. A sala é secreta. Com uma alteração que visasse a modificar o júri brasileiro, aproximando-o, com maior ou menor intensidade, de outros modelos, o sigilo das votações continuaria a ser garantido, de modo que não vejo cláusula constitucional impeditiva nesse aspecto" (Streck, 2001, p.173/174).

Assim, com fulcro no princípio da plenitude de defesa (art. 50, XXXVIII, “a)” da Constituição Federal,, manifestou-se o Superior Tribunal de Justiça no sentido de ser possível ao réu preso sua apresentação à Sessão

Plenária com vestimentas distintas daquelas utilizadas no estabelecimento prisional, haja vista o julgamento perante juízes leigos, eximidos do dever de fundamentar suas decisões, consoante se extrai da ementa abaixo:

"PROCESSO PENAL. RECURSO EM MANDADO DE SEGURANÇA. HOMICÍDIO QUALIFICADO. TRIBUNAL DO JÚRI. INDEFERIMENTO DO PEDIDO DE APRESENTAÇÃO DO RÉU COM ROUPAS CIVIS EM PLENÁRIO. PRINCÍPIO DA PLENITUDE DE DEFESA. AUSÊNCIA DE PREJUÍZO AO PROCESSO. NULIDADE ACOLHIDA. RECURSO PARCIALMENTE PROVIDO. 1. O Tribunal do Júri, juiz natural e soberano para julgar os crimes dolosos contra a vida, é instituição que desempenha papel fundamental na efetividade da justiça e no exercício da sociedade democrática, nos termos preceituados no art. $5^{\circ}$, XXVIII, da Constituição Federal. 2. O Conselho de Sentença, no uso de suas prerrogativas constitucionais, adota o sistema da íntima conviç̧ão, no tocante à valoração das provas, de forma que "a decisão do Tribunal do Júri, soberana, é regida pelo princípio da livre convicção, e não pelo art. 93, IX, da CF." (HC 82.023/RJ, rel. Min. Arnaldo Esteves Lima, Quinta Turma, j. 17/11/2009, DJe 7/12/2009). 3. A Carta Magna prevê a plenitude de defesa como marca característica e essencial à própria instituição do Júri, garantindo ao acusado uma atuação defensiva plena e efetiva, ensinando o doutrinador Guilherme de Souza Nucci que "O que se busca aos acusados em geral é a mais aberta possibilidade de defesa, valendo-se dos instrumentos e recursos previstos em lei e evitando-se qualquer forma de cerceamento. Aos réus, no Tribunal do Júri, quer-se a defesa perfeita, dentro, obviamente, das limitações naturais dos seres humanos." (NUCCI, Guilherme de Souza. Tribunal do Júri. 6. ed. São Paulo: Revista dos Tribunais, 2015. p. 35). 4. Havendo razoabilidade mínima no pleito da defesa, como se vislumbra do pedido pela apresentação do réu em Plenário com roupas civis, resta eivada de nulidade a decisão que genericamente o indefere. 5. A nulidade não exsurge do simples comparecimento do acusado na Sessão Plenária com as vestimentas usuais dos presos, sendo certo que diariamente julgamentos ocorrem nessa condição (...) 7 . Recurso parcialmente provido para cassar a decisão do Juízo da $1^{\mathrm{a}}$ Vara Criminal de 
Poços de Caldas/MG, na ação penal n. ${ }^{\circ}$ 0518.17.013273-3, de forma permitir ao réu, ora recorrente, usar roupas civis na Sessão do Tribunal do Júri."

(STJ, 5 Turma, RMS 60.575/MG, Rel. Ministro Ribeiro Dantas, Brasília, 13 ago. 2019)

Há, inclusive, uma famigerada técnica utilizada pela defesa nos julgamentos do Tribunal do Júri, qual seja, a de que os réus utilizem óculos de leitura durante as sessões. Isso porque tenderiam os jurados a absolver com maior probabilidade indivíduos com suposta aparência intelectual e não violenta (Melo, 2019, s.p). Mais uma vez, verifica-se que a lógica em plenário possui raízes no chamado Direito Penal do autor, punindo-se o indivíduo não pelo fato, mas pelo que ele é ou aparenta ser.

É mister a alusão ao Enunciado de súmula vinculante de número 11, publicada no dia 21 de agosto de 2008, cuja razão de ser se deu a partir dos julgamentos pelo Tribunal do Júri, haja vista a possível influência negativa dos jurados leigos, em razão do uso de algemas pelo réu durante a sessão plenária. Assim dispõe o conteúdo do referido enunciado:

"Só é lícito o uso de algemas em casos de resistência e de fundado receio de fuga ou de perigo à integridade física própria ou alheia, por parte do preso ou de terceiros, justificada a excepcionalidade por escrito, sob pena de responsabilidade disciplinar, civil e penal do agente ou da autoridade e de nulidade da prisão ou do ato processual a que se refere, sem prejuízo da responsabilidade civil do Estado."

A respeito do uso de algemas pelo réu em Plenário do Tribunal do Júri, assevera Guilherme de Souza Nucci:

\footnotetext{
"Manter o réu algemado o tempo todo, especialmente no momento em que é interrogado, quase sem poder expressar-se através de gestos, não nos parece a melhor medida. Em primeiro plano, deve-se destacar que o juiz leigo não tem o mesmo preparo do magistrado togado para ignorar solenemente a apresentação do acusado com algemas. É possível destacar-se em sua mente que os grilhões representariam tanto um símbolo de perigo, quanto de culpa. Outros sistemas processuais, como ocorre nos Estados Unidos e no Reino Unido, buscam preservar a imagem do réu, permitindo-lhe que se sente ao lado de seu defensor no plenário, sem o uso das algemas. Sabe-se, por certo, que a imagem da pessoa submetida a julgamento compõe o quadro idealizado pelos jurados acerca do caso, sendo impossível controlar o grau de emotividade gerado, quando o acusado ingressa no recinto algemado e assim permanece o tempo todo. Estando em disputa interesses cruciais
} 
da pessoa humana e havendo um julgamento a ser proferido sem fundamentação, através do voto secreto, torna-se mais lógico evitar, a qualquer custo, a má apresentação do acusado diante de seus julgadores" (Nucci, 2015, p.720)

Na opinião de Aury Lopes Jr, o sistema da íntima convicção deve ser analisado por meio de críticas, haja vista a arbitrariedade de decisões sem qualquer fundamentação:

"O golpe fatal no júri está na absoluta falta de motivação do ato decisório. A motivação serve para o controle da racionalidade da decisão judicial. Não se trata de gastar folhas e folhas para demonstrar erudição jurídica (e jurisprudencial) ou discutir obviedades. O mais importante é explicar o porquê da decisão, o que o levou a tal conclusão sobre a autoria e materialidade. A motivação sobre a matéria fática demonstra o saber que legitima o poder, pois a pena somente pode ser imposta a quem- racionalmente- pode ser considerado autor do fato criminoso imputado. Como define IBÁÑEZ, o ius dicere em matéria de direito punitivo deve ser uma aplicação/ explicação: um exercício de poder fundado em um saber consistente por demonstradamente bem adquirido. Essa qualidade na aquisição do saber é condição essencial para legitimidade do atuar jurisdicional. A decisão dos jurados é absolutamente ilegítima porque carecedora de motivação. Não há a menor justificação (fundamentação) para seus atos. Trata-se de puro arbítrio, no mais absoluto predomínio do poder sobre a razão. E o poder sem razão é prepotência. A situação ainda é mais grave se considerarmos que a liberdade de convencimento (imotivado) é tão ampla que permite o julgamento a partir de elementos que não estão no processo. A "íntima convicção", despida de qualquer fundamentação, permite a imensa monstruosidade jurídica de ser julgado a partir de qualquer elemento. Isso significa um retrocesso ao Direito Penal do autor, ao julgamento pela "cara”, cor, opção sexual, religião, posição socioeconômica, aparência física, postura do réu durante o julgamento ou mesmo antes do julgamento, enfim, é imensurável o campo sobre o qual pode recair o juízo de (des)valor que o jurado faz em relação ao réu. E, tudo isso, sem qualquer fundamentação” (Lopes Jr, 2014, p.1078/1079).

Nesse sentido, o aspecto polêmico referente ao sistema da íntima convicção no Tribunal do Júri é alvo de debates e discussões. Isso porque, em razão da ausência de fundamentação nas decisões proferidas, os jurados leigos podem projetar seus preconceitos e intolerâncias em seus veredictos, o que compromete, indubitavelmente, a garantia democrática de um julgamento imparcial.

\section{3. $O$ posicionamento simbólico do Ministério Público na sala de audiências criminais}


Com o advento da Lei Orgânica Nacional do Ministério Público, foi positivado, como uma das prerrogativas dos membros do Ministério Público, no exercício de suas atribuições, o assento à direita dos juízes de primeira instância. Nesse sentido, tal regra aplica-se também aos casos de julgamentos pelo Tribunal do Júri, nos quais o membro do Ministério Público, durante a Sessão Plenária, toma seu assento ao lado do juiz presidente, ao passo que, a defesa e o réu (este último, se estiver presente) posicionam-se de forma mais distanciada do local onde permanecem o juiz togado e o promotor de justiça.

Assim dispõe a Lei 8.625/1993, qual seja, a Lei Orgânica Nacional do Ministério Público, em seu art. 41, inciso XI:

"Constituem prerrogativas dos membros do Ministério Público, no exercício de sua função, além de outras previstas na Lei Orgânica:

XI - tomar assento à direita dos Juízes de primeira instância ou do Presidente do Tribunal, Câmara ou Turma."

Além da previsão normativa constante na Lei 8.625/1993 a respeito da prerrogativa de os membros do Ministério Público permanecerem em assentos à direita dos representantes do Poder Judiciário, há a Lei Complementar 75/1993, que, por sua vez, dispõe acerca da organização, das atribuições e do estatuto do Ministério Público da União. Consoante a redação de seu art. 18, inciso I, alínea “a)":

“São prerrogativas dos membros do Ministério Público da União:

I - institucionais:

a) sentar-se no mesmo plano e imediatamente à direita dos juízes singulares ou presidentes dos órgãos judiciários perante os quais oficiem;"

No entanto, do ponto de vista doutrinário, a questão do assento que os membros do Ministério Público tomam nas audiências criminais (e, para fins do presente trabalho, fala-se, de forma específica, durante as Sessões de 
Julgamento do Tribunal do Júri) é bastante controversa, sendo objeto de entendimentos rigorosamente opostos, no tocante à sua constitucionalidade.

\author{
Segundo o entendimento de André Luiz Bogado Cunha, promotor de
} justiça:

“À primeira vista pode parecer sedutora a alegação de que a disposição cênica atual fere o princípio da isonomia das partes e da igualdade de armas, trazendo evidente desequilíbrio nas relações processuais. Os adeptos desta corrente de pensamento afirmam que o Estado não é mais importante que o indivíduo e que nos julgamentos do Tribunal do Júri estaria patente o prejuízo à defesa, pois os jurados, ao verem o promotor de Justiça sentado ao lado e no mesmo nível do magistrado, poderiam confundir suas funções e acreditar que o membro do MP desfrutaria de mais credibilidade e importância do que o advogado (...) Também há uma falsa premissa de que a posição do MP nos plenários do júri teria o condão de influenciar os jurados. A isonomia não se dá pelo assento, mas sim pelas oportunidades oferecidas. Aquela assertiva deve ser levada ao plano objetivo: não basta mera especulação ou suposição, teria de ser provado, de forma inequívoca, que a posição física ocupada pelo MP teria alguma relevância na decisão do colegiado. Se formos partir apenas de conjecturas, podemos afirmar que a defesa que é beneficiada pela postura cênica, já que fica o tempo todo de frente para os jurados, ao passo que o MP fica, via de regra, na lateral, o que prejudica sua visualização. $\mathrm{O}$ assento atual do MP não fere o princípio da isonomia, se fosse assim, a própria disposição física do plenário do STF teria de ser mudada, pois o Procurador Geral da República fica à direita do seu presidente. Será que o STF, que é o guardião da Constituição Federal, agiu, durante décadas, de maneira inconstitucional dentro de sua própria casa?" (Cunha, 2014, s.p).

No entanto, de modo divergente, no sentido de rechaçar a constitucionalidade do assento do Ministério Público ao lado do magistrado, manifesta-se Marcelo Semer, juiz de direito:

"Uma das principais evoluções do processo penal moderno foi a separação entre a
figura do acusador e do juiz. Não à toa, costumava-se denominar inquisitorial o
sistema que mantinha atuação de acusação por parte do magistrado. A partir do
momento em que assumimos o sistema acusatório, com a Constituição de 1988 ,
afastamos figuras que remontavam resquícios dessa atividade inquisitorial, como o
procedimento judicialiforme -em que até a denúncia pelo Ministério Público era
dispensada (...) Mas obstáculo que parece ser ainda mais difícil de transpor tem sido
a desigualdade das partes no arranjo cênico das salas de audiência -simbolismo que
continua a propiciar justamente a confusão que o processo penal vem tentando
depurar há tempos (...)O Ministério Público não é parecerista; nas açães penais
públicas, é o órgão acusatório. Por mais que exista similaridade de carreiras, de
impedimentos ou de vantagens, no processo criminal, promotor jamais pode estar
em situação de equiparação com o juiz. Desempenham funções distintas e todo o
instrumental legislativo vem sendo construído para evitar essa contaminação. O
processo também se demarca pela paridade de armas. Não há como supor que 
acusação e defesa estejam no mesmo patamar diante deste desequilíbrio simbólico (...) Sendo parte no processo penal, não há sentido de que o MP seja alçado a um patamar de igualdade com o julgador. Não há nenhum demérito por aqui: apenas o respeito de que a acusação não pode ser jamais privilegiada, reverenciada ou considerada de forma diversa da defesa (...) Não se pode ignorar, por exemplo, a questão do Júri, em que a decisão está nas mãos de jurados leigos. A impressão que faz do MP uma parte privilegiada, pode causar consequências profundas" (Semer, 2014, s.p).

Consoante se depreende da citação acima, critica-se tal prerrogativa do Ministério Público, no âmbito do processo penal, em razão do fato de que tal estrutura simbólica na sala de audiências apresenta resquícios inquisitoriais. No sistema inquisitório, uma única figura (juiz inquisidor) era responsável por 3 (três) funções: acusar, defender e julgar. De outra sorte, no sistema acusatório, o processo penal rechaça tal concentração de atribuições em uma só pessoa.

Nesse contexto, a questão foi levada ao Superior Tribunal de Justiça. A Quinquagésima Sétima Subseção de Guarulhos da Ordem dos Advogados do Brasil - Seccional de São Paulo apresentou à referida Corte o RHC 13.720/ SP, cuja ementa segue abaixo:

"CRIMINAL. HC. HOMICÍDIO. PLEITO DE ALTERAÇÃO DO POSICIONAMENTO DA ACUSAÇÃO E DEFESA NO JULGAMENTO DO TRIBUNAL DO JÚRI. PRINCÍPIO DA IGUALDADE. EQUIDISTÂNCIA ENTRE O JUIZ E AS PARTES. POSIÇÃO DO PROMOTOR E DO ADVOGADO QUE CONFIGURARIA CONSTRANGIMENTO ILEGAL. INEXISTÊNCIA DE AMEAÇA À LIBERDADE DE LOCOMOÇÃO. RECURSO DESPROVIDO. O fato de o defensor do réu não estar assentado ao lado do Juiz Presidente por ocasião de julgamento na Sessão Plenária do Tribunal do Júri não configura constrangimento ilegal à liberdade de ir e vir. A igualdade entre as partes, defesa e acusação, no Tribunal Popular, é verificada pelo mesmo tempo de que dispõem para que, em pé, da mesma forma, diante dos jurados, possam proferir suas alegações, sustentando a tese defensiva ou acusatória. A posição do patrono do lado do réu possibilita a melhor comunicação entre eles, facilitando eventuais orientações e obtenção de informações para a promoção da defesa. O posicionamento do Ministério Público, que se coloca sentado ao lado do Magistrado Presidente do Tribunal do Júri, decorre da Lei 8.625/93, não significando superioridade em relação ao defensor. Não se configura constrangimento ilegal a ser reparado na via eleita do writ, já que não evidenciada qualquer ameaça ao direito de locomoção do paciente, por abuso de poder ou ilegalidade- o que impede atentar-se aos termos da previsão constitucional que institucionalizou o habeas corpus como meio próprio à preservação do direito de locomoção, quando demonstrada a ofensa ou a ameaça referidas. Recurso desprovido." 


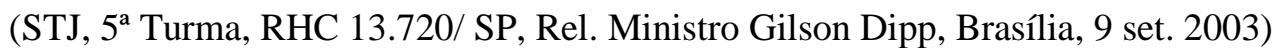

Além disso, há decisão liminar proferida pelo Conselho Nacional de Justiça em sede de Procedimento de Controle Administrativo de no 0001023 25.2011.2.00.0000 (CNJ, PCA 0001023-25.2011.2.00.0000, Relator Emmanoel Campelo, Brasília, 27 nov. 2012), no sentido de que deve ser assegurado aos membros do Ministério Público o assento à direita do juiz, considerando os fundamentos legais outrora apresentados.

Nestes termos, percebe-se que as provocações a órgãos no sentido de se declarar a impossibilidade de o Ministério Público usufruir de tal prerrogativa legal resultaram infrutíferas, no sentido de que não foram reconhecidas eventuais violações a princípios como a igualdade, por exemplo.

No entanto, a ADI 4.768, ainda pendente de julgamento pelo Supremo Tribunal Federal, fora ajuizada pelo Conselho Federal da OAB (constante no rol de legitimados para tal ajuizamento, nos termos do art. 103, inciso VII da Constituição Federal) com intuito de que os dispositivos legais referentes ao art. 18, inciso I, alínea "a)" da Lei Complementar 75/ 93 e art. 41, inciso XI da Lei 8.625/93 sejam declarados inconstitucionais pela Corte Constitucional. Em seus argumentos, ressaltou o Conselho Federal da OAB que não há qualquer inconstitucionalidade quando o membro do Ministério Público toma assento à direita do juiz nos casos em que figura como custus legis do processo. De outra sorte, assim, se o Ministério Público assumisse o manto de acusador, titular da ação penal, seria inconstitucional sua posição à direita do magistrado, por violar o princípio da igualdade e da isonomia processual. 


\section{CONCLUSÃO}

O instituto do Tribunal do Júri e seus princípios correlatos são fruto de uma previsão feita pelo poder constituinte originário na Carta de 1988, o que os confere, desse modo, status de garantia fundamental, sendo considerados impassíveis, assim, de supressão por eventual emenda constitucional. Historicamente, no Brasil, percebe-se a sensibilidade do poder constituinte originário em elevar o instituto do Tribunal do Júri a status de norma constitucional, cujo primeiro marco fora constatado na outorgada Constituição de 1824.

Sob este aspecto, tratando-se de um direito fundamental sob o manto de proteção de cláusula pétrea, é possível conceber a razão de ser do Tribunal do Júri. Consoante os fundamentos democráticos da ordem constitucional vigente, além de garantir a participação popular no poder Judiciário, o referido instituto possui o fito de possibilitar ao réu, acusado de um crime doloso contra a vida, um julgamento feito a partir de seus pares, indivíduos integrantes de seu mesmo seio social, com o objetivo de lhe proporcionar um universo maior de estratégias defensivas em face do poder punitivo estatal (ius puniendi).

Embora tenha o constituinte originário delineado tais previsões, o presente instituto apresenta aspectos polêmicos em sua própria essência, bem como em seu procedimento legal, que obstam a observância da garantia de um julgamento imparcial e permeado de segurança jurídica.

Nesse sentido, a partir das considerações registradas neste trabalho, conclui-se que o quantum de julgadores revela-se insuficiente para formação de margem de segurança nas decisões, haja vista que os veredictos são contabilizados por meio da regra de maioria simples- em um julgamento cujo quórum de votação resulte em 4x3, só há 57,14\% de margem de consenso na 
decisão. Assim, entende-se que tais aspectos deveriam ser revisitados pelo legislador, de modo a aumentar o número legal de jurados no Conselho de Sentença, alterando o sistema de cômputo dos votos (atualmente, maioria simples) para uma regra de maioria qualificada, a qual é vislumbrada em alguns entes federativos dos Estados Unidos, bem como na Inglaterra.

Além disso, percebeu-se que o sistema da íntima convicção obsta a sindicabilidade dos motivos que levaram os jurados a proferirem seus votos em um ou outro sentido. Em outras palavras, a ausência de fundamentação nas respostas aos quesitos, aliada à incomunicabilidade do Conselho de Sentença, são aspectos que obstaculizam o controle de arbitrariedades nas decisões pelo Poder Judiciário. Nesse sentido, com o fito de serem reduzidos eventuais veredictos tomados por motivos arbitrários (cor da pele, religião, exercício do direito ao silêncio pelo réu em julgamento, entre outros), a possibilidade de deliberação entre os jurados, a portas fechadas, como ocorre no júri lusitano, isto é, de forma secreta, seria um fator capaz de reduzir tais deficiências do sistema da íntima convicção.

Por fim, entendeu-se que o local simbólico onde permanece o membro do Ministério Público, durante a sessão plenária de julgamento, pode interferir no processo psicológico de votação pelos jurados, qual seja, ao lado do juiz presidente, figura que goza de status de reverência na sociedade. A despeito de existir manifestação por parte do Superior Tribunal de Justiça e do Conselho Nacional de Justiça no sentido de reafirmar tal prerrogativa legal conferida aos membros do Ministério Público, com a máxima vênia, considera-se tal previsão, especialmente no âmbito do Tribunal do Júri, um prejuízo para a observância de um julgamento imparcial.

Vale destacar que, embora o instituto do Tribunal do Júri, nos termos do ordenamento jurídico pátrio, apresente seus aspectos críticos, consoante fora desenvolvido, trata-se de uma relevante concretização dos princípios democráticos que realizam a ordem constitucional vigente. A participação 
popular na tomada de decisões em âmbito do poder Judiciário possui, indubitavelmente, evidente importância do ponto de vista da democracia. No entanto, tais reflexões críticas são necessárias, com o fito de se refletir acerca de um Tribunal do Júri que assegure, de forma mais palpável, observância aos princípios da imparcialidade do julgador (nesse caso, julgadores) e de segurança jurídica nas decisões.

Acerca da necessidade de reflexão em face dos aspectos polêmicos vislumbrados no Tribunal do Júri, registram-se as palavras do professor Aury Lopes Jr:

"Um dos graves problemas para a evolução de um determinado campo do saber é o repouso dogmático. Quando não se estuda mais e não se questiona as "verdades absolutas". O Tribunal do Júri é um dos temas em que a doutrina nacional desfruta de um longo repouso dogmático, pois há anos ninguém (ousa) questiona(r) mais sua necessidade e legitimidade (...) E os argumentos contrários ao júri seguem, numa lista interminável, e, o que é mais grave, inabaláveis pelos frágeis argumentos dos defensores da instituição. Pensamos que a administração de justiça pode prescindir do Tribunal do Júri, mas, considerando a consagração constitucional, o que impediria a extinção pura e simples, é crucial que se façam profundas alterações estruturais" (Lopes Jr, 2014, p.1075/1082). 


\section{REFERÊNCIAS BIBLIOGRÁFICAS}

BADARÓ, Gustavo Henrique Righi Ivahy; BOTTINI, Pierpaolo Cruz; GOMES FILHO, Antônio Magalhães; MOURA, Maria Thereza Rocha de Assis; PRADO, Geraldo; SANTOS, Leandro Galluzzi dos. As reformas no processo penal: as novas leis de 2008 e os projetos de reforma. São Paulo, Revista dos Tribunais, 2009.

BRASIL. Código de Processo Penal de 1941. Disponível em: <http://www.planalto.gov.br/ccivil_03/decreto-lei/del3689.htm>. Acesso em 27 ago. 2019.

_. Código Penal de 1940. Disponível em: http://www.planalto.gov.br/ccivil_03/decreto-lei/del2848compilado.htm. Acesso em 27 ago. 2019.

Constituição da República dos Estados Unidos do Brasil de 1891. Disponível em: <http://www.planalto.gov.br/ccivil_03/constituicao/constituicao91.htm>. Acesso em 27 ago. 2019.

. Constituição da República dos Estados Unidos do Brasil de 1934.

Disponível em: <http://www.planalto.gov.br/ccivil_03/constituicao/constituicao34.htm>. Acesso em 27 ago. 2019.

. Constituição da República Federativa do Brasil de 1988. Disponível em: <http://www.planalto.gov.br/ccivil_03/constituicao/constituicao.htm>. Acesso em 27 ago. 2019.

- Constituição da República Federativa do Brasil de 1967. 
<http://www.planalto.gov.br/ccivil_03/constituicao/constituicao67.htm〉. Acesso em 29 ago. 2019 . Constituição dos Estados Unidos do Brasil de 1937. Disponível em:

<http://www.planalto.gov.br/ccivil_03/constituicao/constituicao37.htm>. Acesso em 29 ago. 2019.

Constituição dos Estados Unidos do Brasil de 1946. Disponível em:

<http://www.planalto.gov.br/ccivil_03/constituicao/constituicao46.htm>. Acesso em 06 set. 2019.

. Constituição Política do Império do Brazil de 1824. Disponível em: <http://www.planalto.gov.br/ccivil_03/constituicao/constituicao24.htm>. Acesso em 06 set. 2019.

- Decreto de 18 de junho de 1822. Disponível em: <http://www.planalto.gov.br/ccivil_03/decreto/historicos/dim/DIM-18-61822-2.htm>. Acesso em 27 ago. 2019.

_. Lei Complementar $\mathrm{n}^{\mathrm{o}}$ 75/93. Disponível em: <http://www.planalto.gov.br/ccivil_03/LEIS/LCP/Lcp75.htm>. Acesso em 07 nov. 2019.

<http://www.planalto.gov.br/ccivil_03/_Ato2007-

2010/2008/Lei/L11689.htm >. Acesso em 15 nov. 2019.

. Lei Orgânica Nacional do Ministério Público. Disponível em: $<$ http://www.planalto.gov.br/ccivil_03/Leis/L8625.htm>. Acesso em 07 nov. 2019. 
CUNHA, André Luiz Bogado. Constitucionalidade do assento do MP ao lado do juiz.

Disponível

em

http://www.cartaforense.com.br/conteudo/artigos/constitucionalidade-do assento--do-mp-ao-lado-do-juiz/14154> . Acesso em 06 nov. 2019.

FARIA, César. A dúvida é a certeza dos loucos: Tribunal do Júri. Disponível em <http://www.direitodoestado.com.br/colunistas/cesar-faria/a-duvida-e-acerteza-dos-loucos-tribunal-do-juri->. Acesso em 24 out. 2019 / acesso em 24 out. 2019

GUIMARÃES, Cláudio Alberto Gabriel; SILVA, Quezia Jemima Custódio Neto. A eficácia constitucional no Tribunal do Júri: limites de observação do devido processo legal. Revista dos Tribunais, ano 101, volume 922, 2012, p.389-429.

JASPER, Eric Hadmann. A ausência de deliberação no Tribunal do Júri brasileiro. Revista dos Tribunais, ano 97, vol. 878, 2008, p.455-468.

LIMA, Renato Brasileiro de. Manual de Processo Penal. $3^{\text {a }}$ ed. Salvador: Juspodivm, 2015.

LOPES JR., Aury. Direito Processual Penal. 11ª ed. São Paulo: Saraiva, 2014.

MARQUES, José Frederico. A Instituição do Júri. Campinas: Bookseller, 1997.

MELO, João Ozorio de. Caso nos EUA reaviva discussão sobre jurados tenderem a absolver réu de óculos. Disponível em: $<$ https://www.conjur.com.br/2019-jun-08/eua-reaviva-discussao-juri-gostarreu-oculos>. Acesso em 02 nov. 2019. 
NUCCI, Guilherme de Souza. Manual de Processo Penal e Execução Penal. $12^{\mathrm{a}}$ ed. Rio de Janeiro: Forense, 2015.

PACELLI, Eugênio. Curso de Processo Penal. 23ª ed. São Paulo: Atlas, 2019.

PORTUGAL. Código de Processo Penal. Disponível em: <https://elearning.mj.pt/dgaj/dados/0C/0CTEMA27.pdf>. Acesso em 10 set. 2019.

RANGEL, Paulo. Tribunal do Júri: Visão linguística, histórica, social e jurídica. Disponível em: <https://forumdeconcursos.com/wpcontent/uploads/wpforo/attachments/2/2009-Tribunal-do-Jri-VisoLingustica-Histrica-Social-e-Jurdica-2018-Paulo-Rangel.pdf $>$. Acesso em 14 set. 2019.

ROUSSEAU, Jean-Jacques. Do contrato social. Disponível em: <http://www.ebooksbrasil.org/adobeebook/contratosocial.pdf>. Acesso em 18 nov. 2019.

SEMER, Marcelo. Inconstitucionalidade do assento do MP ao lado do juiz. Disponível em $<$ http://www.cartaforense.com.br/conteudo/artigos/inconstitucionalidadedo-assento--do-mp-ao-lado-do-juiz/14153>. Acesso em 06 nov. 2019

SILVA, Germano Marques da. Curso de Processo Penal. v.3. Lisboa: Verbo, 2000 .

STRECK, Lenio Luiz. Tribunal do Júri: símbolos \& rituais. Disponível em $<$ http://arquimedes.adv.br/livros100/Tribunal\%20do\%20Juri\%20$\% 20$ Simbolos\%20e\%20Rituais\%20-\%20Lenio\%20Luiz\%20Streck.pdf $>$. Acesso em 05 nov. 2019. 
TJSC. Resolução $\mathrm{n}^{\circ}$ 18/06. Disponível em: $<$ http://busca.tjsc.jus.br/buscatextual/integra.do?cdSistema=1\&cdDocument $\mathrm{o}=797 \& \mathrm{~cd}$ Categoria $=1 \& \mathrm{q}=\&$ frase $=\&$ excluir $=\&$ qualquer $=\&$ prox $1=\&$ prox 2 $=\&$ proxc $=>$. Acesso em 28 out. 2019.

WHITAKER, Firmino. Jury. 6ª ed. São Paulo: Livraria Academica, 1930. 